\title{
Development of a lean manufacturing framework to enhance its adoption within manufacturing companies in developing economies
}

Gunjan Yadav, Sunil Luthra, Donald Huisingh, Sachin Kumar Mangla, Balkrishna Eknath Narkhede and Yang Liu

The self-archived postprint version of this journal article is available at Linköping University Institutional Repository (DiVA):

http://urn.kb.se/resolve?urn=urn:nbn:se:liu:diva-163018

N.B.: When citing this work, cite the original publication.

Yadav, G., Luthra, S., Huisingh, D., Mangla, S. K., Narkhede, B. E., Liu, Y., (2020), Development of a lean manufacturing framework to enhance its adoption within manufacturing companies in developing economies, Journal of Cleaner Production, 245, 118726.

https://doi.org/10.1016/j.jclepro.2019.118726

Original publication available at:

https://doi.org/10.1016/j.jclepro.2019.118726

Copyright: Elsevier

http://www.elsevier.com/

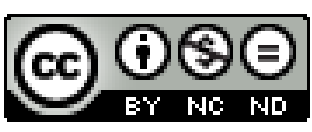




\section{Journal Pre-proof}

Development of a lean manufacturing framework to enhance its adoption within manufacturing companies in developing economies

Gunjan Yadav, Sunil Luthra, Donald Huisingh, Sachin Kumar Mangla, Balkrishna Eknath Narkhede, Yang Liu

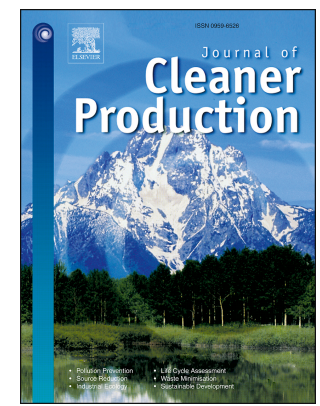

PII: S0959-6526(19)33596-6

DOI: https://doi.org/10.1016/j.jclepro.2019.118726

Reference: JCLP 118726

To appear in: Journal of Cleaner Production

Received Date: 13 May 2019

Revised Date: 7 September 2019

Accepted Date: 4 October 2019

Please cite this article as: Yadav G, Luthra S, Huisingh D, Mangla SK, Narkhede BE, Liu Y, Development of a lean manufacturing framework to enhance its adoption within manufacturing companies in developing economies, Journal of Cleaner Production (2019), doi: https://doi.org/10.1016/ j.jclepro.2019.118726.

This is a PDF file of an article that has undergone enhancements after acceptance, such as the addition of a cover page and metadata, and formatting for readability, but it is not yet the definitive version of record. This version will undergo additional copyediting, typesetting and review before it is published in its final form, but we are providing this version to give early visibility of the article. Please note that, during the production process, errors may be discovered which could affect the content, and all legal disclaimers that apply to the journal pertain.

(C) 2019 Published by Elsevier Ltd. 


\title{
Development of a lean manufacturing framework to enhance its adoption across manufacturing organisations of developing economies
}

\author{
Gunjan Yadav \\ Assistant Professor, Production Engineering Department, \\ Veermata Jijabai Technological Institute (VJTI), Mumbai-400019, Maharashtra, India \\ E-mail: gunjanyadav86@gmail.com \\ Sunil Luthra* \\ Assistant Professor, Department of Mechanical Engineering, \\ State Institute of Engineering \& Technology, Nilokheri-132117, Haryana, India \\ E-mail: sunilluthra1977@gmail.com \\ Prof. Donald Huisingh \\ The Institute for a Secure and Sustainable Environment, \\ University of Tennessee, Knoxville- 37996, U.S.A. \\ Editor-in-Chief, Emeritus- Journal of Cleaner Production \\ E-mail: dhuisingh@utk.edu

\section{Sachin Kumar Mangla} \\ Lecturer in Knowledge Management and Business Decision Making \\ Plymouth Business School (PBS), University of Plymouth- PL4 8AA, United Kingdom \\ E-mail: sachin.kumar@plymouth.ac.uk; sachinmangl@gmail.com
}

\section{Balkrishna Eknath Narkhede}

Associate Professor, Industrial Engineering \& Manufacturing System, NITIE, Mumbai-400087, India

E-mail: benarkhede1@gmail.com

\author{
Yang Liu \\ Department of Management and Engineering, \\ Linköping University, Linköping-SE-581 83, Sweden \\ E-mail: yang.liu@liu.se
}

*Corresponding Author 


\section{Graphical Abstract}

Identify the key drivers that facilitate implementation of lean manufacturing framework for manufacturing organisations in the context of developing economies from existing literature

Assemble an expert panel in case organisation to evaluate and categorise the identified drivers among six major groups and the related sub-groups and prepare inputs for paired comparisons

Apply the fuzzy Analytical Hierarchy Approach to compute the weights and consistency check of major and sub-groups of lean manufacturing drivers

Apply Decision Making Trial and Evaluation Laboratory approach to compute the cause and effect lean manufacturing drivers for initial development

Share the findings of proposed lean manufacturing framework with the case organisation and monitor the change in lean performance metrics for the time span of one year

Discuss the findings and present the implications of this study for researchers and practitioners and future scope 


\title{
Development of a lean manufacturing framework to enhance its adoption within manufacturing companies in developing economies
}

\begin{abstract}
The urgent need to reduce negative corporate environmental impacts while enhancing their financial strength and positive societal benefits is attracting company leaders to implement various quality improvement systems such as lean manufacturing, six sigma, sustainable manufacturing, and circular economy concepts, approaches and technologies. All of these approaches are valuable, with Lean Manufacturing (LM) among the leading systems, if implemented within an appropriate framework. In that context, the objective of the authors was to document the drivers for improving implementation of LM within manufacturing companies. Implementation of LM practices is already providing competitive advantages such as improvements in product quality, productivity, worker health and safety and customer satisfaction in developed countries but has not been widely implemented in companies in developing countries. To help to enhance implementation of LM in developing countries, the authors developed a framework for enhancing the adoption of lean manufacturing processes in such companies. The hybrid Fuzzy Analytical Hierarchy Process (FAHP)- Decision Making Trial and Evaluation Laboratory (DEMATEL) tools were used as the framework to identify and to quantify the interrelationships among the drivers for implementation of LM. This hybrid approach facilitated documentation of the relative importance and priority of the thirty-one lean manufacturing drivers. The results revealed that improved shop-floor management, quality management, and manufacturing strategy drivers were among the most critical drivers, which enhance LM adoption. These findings are beneficial for company leaders and researchers working to improve environmental, economic and societal health, especially within companies in developing countries.
\end{abstract}

Keywords: Lean Manufacturing (LM); DEMATEL; Drivers; Enablers; Manufacturing industries; Multi Criteria Decision Making (MCDM)

\section{Introduction to Existing LM Frameworks}

Although, there is an increase in the number of documented benefits to companies, which implemented Lean Manufacturing (LM) literature, there is also information from a large 
number of companies, which report about LM adoption failures (Henao et al., 2019). Fewer firms were successful in adoption of LM because of non-availability of frameworks to support LM implementation processes (Jadhav et al., 2014). The LM oriented research performed in US firms, documented that only thirty percent of LM implementing organisations achieved the potential benefits defined in the early stages of project execution (Gandhi et al., 2018). In the United Kingdom, the success rate was only twenty-five percent; which reflects upon the serious challenges for LM implementing organisations (Hofer et al., 2012; Ramesh and Kodali, 2012; Bhasin, 2013). This may be due to the fact that the available adoption frameworks, were designed for large-scale organisations (Alhuraish et al., 2017). But, the reality is that there are far more Small and Medium Enterprises (SMEs) than large scale industries. This suggests that there is an urgent need to perform research that is focussed on the development of LM implementation frameworks within SMEs. However, until now, only a minority of SME company leaders have showed interest in implementing (Helleno et al., 2017). Moyano-Fuentes and Sacristán-Díaz (2012) reported that poor consideration of LM drivers was one of the major reasons behind poor LM adoption. Adoption of LM requires a structured process and an effective roadmap (Anvari et al., 2014), and a better understanding about the intensity of LM drivers (Duarte and Cruz-Machado, 2009; Carvalho et al., 2011).

In recent years, China has emerged as the global leader as an outsourcing hub due to low manufacturing costs and low costs of labour (Ramos et al., 2018). China is especially a leader in production of electronic products. They are considered to be the masters in producing the prototypes of electronic products at the lowest possible prices (Farias et al., 2019). This has been helped by their extensive adoption of LM practices, because LM practices are especially advantageous in companies that are mass producers of products. Researchers including, (Caldera et al., 2019). Storch and Lim (1999) have documented, that even a reduction of 2-3 seconds within the production process can result in huge financial savings. Hence, the LM practices are very popular among Chinese companies. But in comparison, companies in other developing countries have seriously struggled in adopting LM.

Although the LM concept emerged in the 1960s, most companies have had difficulties in successfully implementation of LM. Researchers have documented that LM adoption rates across developed economies is much higher than the developing economies. This is due to the existence of the dominance of large-scale companies in developed economies, which are highly successful in implementing LM. But in developing economies, which have a preponderance of SME's and poor educational and supportive infrastructures, they continue 
to have difficulties in successfully implementing LM. Therefore, there is an increasing need for providing a driver-based framework and training for implementing LM in SME's in developing countries. Such a framework can increase the percentage of companies, which successfully implement LM and with that, increased energy and material's efficiency and enhanced product quality and worker health and safety.

But, merely developing a helpful framework will not be beneficial until the framework has been verified through case studies or Multi Criteria Decision Making (MCDM) approaches have verified the applicability of the developed framework. Belekoukias et al. (2014) found that there are several LM frameworks available but few have been verified through appropriate statistical procedures in real world company adoptions. Although the MCDM domain offers many approaches that can be utilised by researchers working in LM and can provide flexibility in justifying the developed framework, many researchers have only developed theoretical and conceptual models for LM adoption but they lacked validation, which contributed to the low frequency of successful implementation of LM in SMEs.

Despite several successful applications of LM in large-scale industries, the SMEs continue to have difficulties in adopting LM (Panwar et al., 2015). Many case studies in the Indian context reported LM failures in SMEs and concluded that the Indian context is far from being ready for wide-spread, successful, adoption of LM (Thanki and Thakkar, 2014). Some researchers emphasised that there is an urgent need for providing leaders of SMEs with clear instructions on the key drivers that can help them to successfully implement LM and to achieve improvement in their company's performance (Hofer et al., 2012). Many researchers have developed lists of drivers for LM adoption but they did not investigate the intensity of influence of the drivers in successful LM adoption (Ramesh and Kodali, 2012). Therefore, there is need for research that documents the drivers, their intensities and their interrelationships.

To make progress on this journey, the authors of this article began by reviewing relevant literature on LM drivers (Shamah, 2013a; Stentoft Arlbjørn and Vagn Freytag, 2013). Accordingly, the objectives of the authors were:

- To identify and assess the intensity of key lean manufacturing drivers that assist LMs adoption in manufacturing companies in developing economies;

- To develop a LM implementation framework and to analyse the inter-relationships among the drivers;. 
- To validate the conceptual framework by using case methodology in a real manufacturing company.

To achieve these objectives, initially, an exhaustive literature review was performed to explore the key LM drivers reported by various researchers in the context to manufacturing companies of developing economies. Further, a case company, which manufactures pump parts, was selected for an in-depth case study. An expert panel (see section 4 for details) was formed within the organisation to finalise the LM drivers and develop a framework suitable for present research work. The expert panel was engaged to develop the inputs for the hybrid fuzzy AHP-DEMATEL approach. The fuzzy AHP was employed to identify the intensity of influence of LM drivers; while, DEMATEL was used to analyse the inter-relationship among the constructs (LM drivers) of the developed framework. The developed framework was supplied to the case company to enhance lean manufacturing adoption. Furthermore, before and after performances of the case company were documented to validate the framework developed in this study. This paper is comprised of the following seven sections:

Section 1 Contains the introduction;

Section 2 Contains the literature review of LM drivers reported by researchers. It highlights the gaps observed in existing LM frameworks;

Section 3 Outlines the research methodology used in the paper;

Section 4 Presents the details of the framework development and its testing within the selected case study company;

Section 5 Summarises the findings and the discussion of the analysis of the case study;

Section 6 Highlights implications of the findings of this paper, for company leaders and for researchers;

Section 7 Summarises the conclusions and highlights urgently needed future research.

\section{Literature Review}

It is important to build upon the relevant articles from the literature to effectively achieve the defined objectives. For this purpose, the systematic literature review approach adopted by (Tranfield et al., 2003; Yadav and Desai, 2016) was employed for this literature review. For conducting the comprehensive literature review, initially; the articles related to LM frameworks and drivers were searched for on Scopus and Web of Science by using the 
following key words, "lean manufacturing frameworks", "lean frameworks", "lean drivers", "lean enablers", lean critical success factors". The relevant articles published in the LM domain from 1998 to April 2019 were considered. To ensure the quality of articles, only journal articles were included while all other types of articles such as conference articles, book chapters, short surveys, editorial notes etc. were excluded. Finally, the forward snowball and backward snowball approach (Yadav et al., 2018) was used to eliminate duplicity and to include all relevant papers.

\subsection{Lean Manufacturing Drivers Reported in the Selected Literature}

The LM drivers were explored through the literature review and were tabulated as shown in Table 1. The drivers basically helped the researchers in diagnosing the key areas that needed to be addressed. By carefully reviewing areas and by developing the strategies to implement them, it will be easier for practitioners to implement LM in their companies. In the literature review, several sets of LM drivers were identified that were general to all sectors and which, were specific to manufacturing, service and healthcare sectors. Because the focus of this research was on manufacturing companies, the drivers reported for other sectors were excluded. A total of thirty-one LM drivers were reported by various researchers, which were selected for analysis in this research (See Table 1).

Table 1: The LM drivers identified through the literature review applicable to manufacturing companies

\begin{tabular}{l|l|l|l}
\hline $\begin{array}{l}\text { S. } \\
\text { No. }\end{array}$ & $\begin{array}{l}\text { Lean Manufacturing } \\
\text { drivers }\end{array}$ & Description & Literature support \\
\hline 1 & Production Scheduling & $\begin{array}{l}\text { It includes implementation of continuous flow } \\
\text { processes which provide support for achieving } \\
\text { production of standardised products }\end{array}$ & $\begin{array}{l}\text { (Bamber and Dale, 2000; } \\
\text { Panizzolo et al., 2012) }\end{array}$ \\
\hline 2 & $\begin{array}{l}\text { Effective utilisation of } \\
\text { resources }\end{array}$ & $\begin{array}{l}\text { It can be achieved by effective allocation and } \\
\text { monitoring of resources within the entire system }\end{array}$ & $\begin{array}{l}\text { (Azadegan et al., 2013; } \\
\text { Pernstål et al., 2015) }\end{array}$ \\
\hline 3 & $\begin{array}{l}\text { Effective management } \\
\text { of inventory }\end{array}$ & $\begin{array}{l}\text { It can be achieved by utilising Kanban practices } \\
\text { and implementing just-in-time' methodologies } \\
\text { within the company }\end{array}$ & $\begin{array}{l}\text { (Bayou and Korvin, 2008; } \\
\text { Gurumurthy and Kodali, } \\
\text { 2008) }\end{array}$ \\
\hline 4 & $\begin{array}{l}\text { Control of product } \\
\text { flow }\end{array}$ & $\begin{array}{l}\text { It refers to adoption of forecasting approaches and } \\
\text { monitoring of takt time (Average time taken for } \\
\text { production of one unit) }\end{array}$ & $\begin{array}{l}\text { (Hodge et al., 2011; } \\
\text { Lyons et al., 2013) }\end{array}$ \\
\hline 5 & Reduction of cycle & $\begin{array}{l}\text { It can be achieved by minimising non-value-added } \\
\text { activities and avoiding bottlenecks by adopting } \\
\text { Poka Yoke }\end{array}$ & $\begin{array}{l}\text { (Vinodh et al., 2011; Julia } \\
\text { time al., 2014) }\end{array}$ \\
\hline
\end{tabular}




\begin{tabular}{|c|c|c|c|}
\hline 6 & $\begin{array}{l}\text { Safety improvement } \\
\text { initiatives }\end{array}$ & $\begin{array}{l}\text { It includes usage of safety equipment and } \\
\text { maintaining cleanliness on shop floor which } \\
\text { enhances protection of employees }\end{array}$ & $\begin{array}{l}\text { (Jadhav et al., 2014; } \\
\text { Zhou, 2016) }\end{array}$ \\
\hline 7 & $\begin{array}{l}\text { Reduction of setup } \\
\text { time }\end{array}$ & $\begin{array}{l}\text { It includes the use of standardized jigs and } \\
\text { fixtures, availability of checklists for guiding rapid } \\
\text { and consistent setups and detailed instructions for } \\
\text { changeovers }\end{array}$ & $\begin{array}{l}\text { (Soriano } \square \text { Meier et al., } \\
\text { 2011; Jasti and Kodali, } \\
\text { 2014) }\end{array}$ \\
\hline 8 & Quality product design & $\begin{array}{l}\text { It involves achieving zero defects by utilising the } \\
\text { equipment that can detect defects and can provide } \\
\text { solutions by eliminating the root cause(s) }\end{array}$ & $\begin{array}{l}\text { (Huo et al., 2019; Leme et } \\
\text { al., 2018) }\end{array}$ \\
\hline 9 & $\begin{array}{l}\text { Aligned distribution } \\
\text { management across } \\
\text { networks }\end{array}$ & $\begin{array}{l}\text { This can be achieved by adopting shared } \\
\text { distribution facilities and using optimisation } \\
\text { approaches for transportation systems }\end{array}$ & $\begin{array}{l}\text { (Fercoq et al., 2016; } \\
\text { Thanki et al., 2016; } \\
\text { Kurilova-Palisaitiene et } \\
\text { al., 2018) }\end{array}$ \\
\hline 10 & $\begin{array}{l}\text { Effective strategies for } \\
\text { marketing } \\
\text { management }\end{array}$ & $\begin{array}{l}\text { This includes the planning for promotion, usage of } \\
\text { forecasting techniques and enhancing pull systems }\end{array}$ & $\begin{array}{l}\text { (Gandhi et al., 2018; Huo } \\
\text { et al., 2019) }\end{array}$ \\
\hline 11 & $\begin{array}{l}\text { Standardise product } \\
\text { development } \\
\text { approaches }\end{array}$ & $\begin{array}{l}\text { It can be achieved by standardising the parts and } \\
\text { by integrating design for manufacturing as integral } \\
\text { in the early product/service system designs }\end{array}$ & $\begin{array}{l}\text { (Duarte and Cruz- } \\
\text { Machado, 2009; } \text { Gupta } \\
\text { and Jain, 2013) }\end{array}$ \\
\hline 12 & $5 \mathrm{~S}$ & $\begin{array}{l}\text { It refers to effective housekeeping, standardising } \\
\text { and sustaining them effectively }\end{array}$ & $\begin{array}{l}\text { (Bayou and Korvin, 2008; } \\
\text { Matt and Rauch, 2013) }\end{array}$ \\
\hline 13 & Value stream mapping & $\begin{array}{l}\text { It includes mapping of the current status of } \\
\text { activities, diagnosing the NVA activities and by } \\
\text { providing suggestions for developing future state } \\
\text { activities map }\end{array}$ & $\begin{array}{l}\text { (Bhaskaran, 2012; } \\
\text { Rahman and Karim, 2014; } \\
\text { Zhou, 2016) }\end{array}$ \\
\hline 14 & Waste analysis & $\begin{array}{l}\text { It can be achieved by identifying different types of } \\
\text { wastes that lead to development of non-value- } \\
\text { added activities }\end{array}$ & $\begin{array}{l}\text { (Shah and Ward, 2007; } \\
\text { Marinescu and Toma, } \\
\text { 2008; Matt and Rauch, } \\
\text { 2013) }\end{array}$ \\
\hline 15 & $\begin{array}{l}\text { Total quality } \\
\text { management }\end{array}$ & $\begin{array}{l}\text { It includes adoption of innovative quality practices } \\
\text { and commitment of top management and strategic } \\
\text { planning of all production processes }\end{array}$ & $\begin{array}{l}\text { (Panizzolo, } \\
\text { Marinescu and Toma, } \\
\text { 2008; Ar, 2012) }\end{array}$ \\
\hline 16 & $\begin{array}{l}\text { Total productive } \\
\text { maintenance }\end{array}$ & $\begin{array}{l}\text { It includes maintenance practices that prevent or } \\
\text { reduce frequency of system breakdowns and helps } \\
\text { to ensure smooth execution of all production- } \\
\text { related activities }\end{array}$ & $\begin{array}{l}\text { (Seyedhosseini et al., } \\
\text { 2013; Zhou, 2016) }\end{array}$ \\
\hline 17 & $\begin{array}{l}\text { Cellular } \\
\text { manufacturing }\end{array}$ & $\begin{array}{l}\text { It includes mapping of similar activities, for } \\
\text { developing the product families and preparing the } \\
\text { work cells systematically }\end{array}$ & $\begin{array}{l}\text { (Detty and Yingling, } \\
\text { 2010; Green et al., 2010) }\end{array}$ \\
\hline
\end{tabular}




\begin{tabular}{|c|c|c|c|}
\hline 18 & $\begin{array}{l}\text { Technology } \\
\text { management }\end{array}$ & $\begin{array}{l}\text { It includes adoption of advanced technologies that } \\
\text { can help to facilitate the reduction of production } \\
\text { lead time and to enhance product quality }\end{array}$ & $\begin{array}{l}\text { (Singh et al., } 2010 \text {; } \\
\text { Soriano } \square \text { Meier et al., } \\
\text { 2011) }\end{array}$ \\
\hline 19 & $\begin{array}{l}\text { Standardisation of } \\
\text { work }\end{array}$ & $\begin{array}{l}\text { It can be achieved by aligning the process } \\
\text { operations and by adopting standardised work } \\
\text { procedures }\end{array}$ & $\begin{array}{l}\text { (Helleno et al., 2017; } \\
\text { Farias et al., 2019) }\end{array}$ \\
\hline 20 & oce & $\begin{array}{l}\text { It can be achieved by observing the fluctuating } \\
\text { demands and by standardising the processes for } \\
\text { product and production optimisation }\end{array}$ & $\begin{array}{l}\text { (Panizzolo, 1998; } \\
\text { Chiarini, 2011; Bhasin, } \\
\text { 2013) }\end{array}$ \\
\hline 21 & $\begin{array}{l}\text { Continuous } \\
\text { improvement approach }\end{array}$ & $\begin{array}{l}\text { It includes adoption of Kaizen and by continuously } \\
\text { diagnosing the activities that lead to non-value } \\
\text { addition }\end{array}$ & $\begin{array}{l}\text { (Bayou and Korvin, 2008; } \\
\text { Matt and Rauch, 2013) }\end{array}$ \\
\hline 22 & Visua & $\begin{array}{l}\text { It refers to visualisation of activities for } \\
\text { identification of wastes by visual aids and by } \\
\text { visual information systems }\end{array}$ & $\begin{array}{l}\text { (Bhasin, 2011b; Ar, 2012; } \\
\text { Bhaskaran, 2012) }\end{array}$ \\
\hline 23 & $\begin{array}{l}\text { Appropriate supplier } \\
\text { evaluation strategies }\end{array}$ & $\begin{array}{l}\text { Mapping the performance of suppliers by } \\
\text { estimating their comparative costs and by } \\
\text { promoting 'just-in-time,' deliveries }\end{array}$ & $\begin{array}{l}\text { (Bhaskaran, 2012; } \\
\text { Rahman and Karim, 2014; } \\
\text { Zhou, 2016) }\end{array}$ \\
\hline 24 & $\begin{array}{l}\text { Mapping the delivery } \\
\text { performance }\end{array}$ & $\begin{array}{l}\text { By understanding the uncertainties in the demand } \\
\text { and by initiating measures to provide the products } \\
\text { by the customer's desired delivery time }\end{array}$ & $\begin{array}{lr}\text { (Marksberry, 2011; } \\
\text { Ramesh and Kodali, } \\
\text { 2012; Thanki and } \\
\text { Thakkar, 2014) }\end{array}$ \\
\hline 25 & Supp & $\begin{array}{l}\text { Integrating suppliers with the system processes by } \\
\text { training them and by building long-term, } \\
\text { supportive relationships }\end{array}$ & $\begin{array}{l}\text { (Detty and Yingling, } \\
\text { 2010; Green et al., 2010) }\end{array}$ \\
\hline 26 & $\begin{array}{l}\text { Identifying the } \\
\text { requirements of } \\
\text { customers }\end{array}$ & $\begin{array}{l}\text { Understanding the product modifications by } \\
\text { considering the requirements of customers and } \\
\text { working with them accordingly }\end{array}$ & $\begin{array}{l}\text { (Ramos et al., 2018; } \\
\text { Caldera et al., 2019; } \\
\text { Henao et al., 2019) }\end{array}$ \\
\hline 27 & $\begin{array}{l}\text { Monitoring feedback } \\
\text { from customers }\end{array}$ & $\begin{array}{l}\text { Developing an effective customer feedback system } \\
\text { by responding to their complaints and } \\
\text { recommendations }\end{array}$ & $\begin{array}{l}\text { (Alhuraish et al., 2017; } \\
\text { Huo et al., 2019) }\end{array}$ \\
\hline 28 & $\begin{array}{l}\text { Adequate workforce } \\
\text { evaluation strategies }\end{array}$ & $\begin{array}{l}\text { Assigning the effective appraisal programs and } \\
\text { incentives for lean project member's performance }\end{array}$ & $\begin{array}{l}\text { (Azadegan et al., 2013; } \\
\text { Pernstål et al., 2015) }\end{array}$ \\
\hline 29 & $\begin{array}{l}\text { Workforce training } \\
\text { and education system }\end{array}$ & $\begin{array}{l}\text { Providing effective training and education for } \\
\text { better understanding and implementation of lean } \\
\text { manufacturing activities }\end{array}$ & $\begin{array}{l}\text { (Duarte and } \text { Cruz- } \\
\text { Machado, 2009; } \text { Gupta } \\
\text { and Jain, 2013) }\end{array}$ \\
\hline 30 & Employee proficiency & $\begin{array}{l}\text { It includes enhancement of multi-functionality of } \\
\text { employees by changing their work programs and } \\
\text { thereby making them adaptive for new workforce } \\
\text { challenges }\end{array}$ & $\begin{array}{l}\text { (Gurumurthy and Kodali, } \\
\text { 2008; Vinodh et al., } \\
\text { 2011) }\end{array}$ \\
\hline
\end{tabular}




\begin{tabular}{l|l|l|lr}
\hline 31 & Workforce & It refers to encouragement of employees to become & (Detty and Yingling, \\
& empowerment \& & actively involved in the planning and & $2010 ; \quad$ Bortolotti and \\
involvement & $\begin{array}{l}\text { implementation of lean projects and by assigning } \\
\text { them explicit responsibilities }\end{array}$ & $\begin{array}{l}\text { Romano, 2012; Vinodh } \\
\text { and Joy, 2012) }\end{array}$ \\
\hline
\end{tabular}

Production scheduling and effective utilisation of resources were among the key drivers that help in implementation of LM (Matt and Rauch, 2013). By production scheduling the production work can be standardised throughout the production processes (Shah and Ward, 2007). Similarly, by reviewing 'Just-In-Time,' manufacturing systems, Kanban practices, and by effectively allocating and monitoring the resources within the system, the entire shop-floor management can be more effectively managed (Teichgräber and Bucourt, 2012). However, the control of product flow and safety improvement initiatives strengthen the involvement of employees and help to keep employees and management motivated (Panizzolo, 1998). By reducing cycle times, set-up times and by making checklists for set-ups available, improvements in shop-floor management usually results (Panwar et al., 2015). By linking these drivers together, all shop-floor activities can be synchronised effectively, which can lead to enhanced productivity of the entire production system (Thanki and Thakkar, 2014).

Quality product design and aligned distribution management across networks plays a vital role in efficient and effective production (Hofer et al., 2012). It consists of striving to achieve zero defects by utilising the proper equipment that can detect defects and by providing solutions for root causes of the problems. Thereby, more effective management can be achieved by adopting shared distribution facilities and by using optimisation techniques and enhancing the pull systems (Anvari et al., 2014). Researchers including (Shetty et al., 2010; Ramesh and Kodali, 2012; Soriano-Meier et al., 2011; Jasti and Kodali, 2014) suggested adoption of strategies for marketing management and for following standardised product development approaches as a manufacturing strategy which supports LM adoption.

By building upon the drivers listed in Table 1, LM can be smoothly adopted across the entire system.

Several researchers discussed quality management practices such as 5S (Seiri, Seiton, Seiso, Seiketsu, Shitsuke), value stream mapping, waste analysis, total quality management and total productive maintenance as essential components that need to be adopted to facilitate the adoption of LM (Marksberry, 2011). Generally, 5S refers to effective housekeeping, standardising and sustaining them effectively (Jadhav et al., 2014). It consists of five elements namely; sort, set in order, shine, standardise, and sustain, which helps to ensure 
effective operation of the entire system (Bhasin, 2011b). Similarly, the value stream mapping refers to mapping the current activities, to develop the current state map to identify the key areas for which improvement is needed and to explore the non-value-added activities, to eliminate those activities or processes, which do not contribute to increasing the production systems value (Mangla et al., 2019).

By incorporating the improved solutions, a new state map can be developed as proposed by Singh et al. (2010). However, total productive maintenance involves practices that help in preventing or minimising breakdowns and supports smooth implementation of activities to maintain a smooth and top quality of the production system's work flow (Singer and Becker, 2013). Standardisation of work, employing the continuous improvement approach, visual management, technology management and cellular manufacturing emerged as key drivers for effective implementation of lean manufacturing (Chiarini, 2011). The cellular manufacturing includes mapping of similar activities, developing the product families and preparing the work cell whereas, visual management refers to visualisation of activities for identification of wastes by visual aids and by visual information systems (Manzouri et al., 2013).

However, the process focus was achieved by observing the fluctuations in demands and by standardising the processes for optimised work flows (Shamah, 2013b). The technology management includes the adoption of advanced technologies, which can assist in reduction of lead-times and can reduce or eliminate non-value added activities (Arya and Jain, 2014). The continuous improvement approach includes adoption of Kaizen that focuses upon continuously diagnosing the key areas of improvement (Hasle et al., 2012). Kaizen refers to change for betterment and helps in eliminating non-value-added activities that directly support LM. Appropriate supplier evaluation strategies, mapping the delivery performance, supplier development, identifying the requirements of customers and monitoring the feedback from customers are the most important drivers reported by researchers in the evaluated literature ( Setijono et al., 2010; Cudney and Elrod, 2011; Moyano-Fuentes and SacristánDíaz, 2012; Gupta and Jain, 2013; Stentoft Arlbjørn and Vagn Freytag, 2013).

Effective strategies for supplier evaluation should be adopted and the supplier's performance should be monitored by estimating its costs and by promoting 'Just-In-Time,' approaches to minimise inventory storage costs (Yadav et al., 2018) which helps to reduce or eliminate storage wastes and to promote implementation of LM. Integrating suppliers within the system processes by training them and by building long-term relationships, leads to more reliable supplier development (Jasti and Kodali, 2014). In developing an effective customer feedback system, prompt, polite and helpful responses to their complaints help the company to make 
needed corrections to avoid problems in the future and thereby, build loyal customers (Luthra et al., 2019). These approaches will help to improve the company's sustainable profitability (Jasti and Sharma, 2014). Working with customers to better understand their needs and by making product modifications accordingly, helps the company ensure repeat customers (Duarte and Cruz-Machado, 2009).

Adequate work force strategies, work force training and an employee educational system, monitoring employee proficiency, work force empowerment and involvement are among the approaches needed to help companies to move effectively in implementing LM (Carvalho et al., 2011). Using effective appraisal strategies and effective incentives for lean project members, helps to develop and to support a positive and productive workforce (Pavnaskar et al., 2003; Marodin and Saurin, 2013; Pakdil and Leonard, 2014). By providing effective training and education for better understanding of LM activities elevates the importance of the workforce training and educational system (Machado and Tavares, 2008; Mcdonald et al., 2009). Employee proficiency includes enhancement of multi-functionality of employees by rotating their work programs and thereby making them more adaptive for new workforce challenges (Machado and Leitner, 2010; Upadhye et al., 2010). Workforce empowerment and involvement can be enhanced by encouraging the employees' active participation in LM projects and by assigning important responsibilities to them (Yadav et al., 2018).

\subsection{Literature Gaps}

Based on the literature review conducted to explore the LM drivers, the following gaps were identified:

- Many studies on LM framework development (Johansen and Walter, 2007; Gao and Low, 2014; Yadav et al., 2017) were conceptual and were not verified, this creates uncertainty among company leaders in regard to LM's adoption. Although, several researchers (Zargun and Al-Ashaab, 2013; Alhuraish et al., 2017) identified drivers for successful LM adoption, few modelled them into a framework.

- Two research teams (Gandhi et al., 2018; Caldera et al., 2019) identified the weights of different LM drivers but did not explore the inter-relationships among them, which generated uncertainty about their behaviour during LM adoption processes.

- Two driver-oriented studies (Seth and Panigrahi, 2015; Yadav and Desai, 2017a) were focussed on managerial components but they did not focus upon the LM implementation drivers. Most of the researchers highlighted identification of non- 
value adding activities for the framework development. However, limited research was done on the roles of quality practices in LM frameworks needed to ensure higher quality throughout the systems.

- The applications of the LM frameworks were documented in some healthcare (Hussain et al., 2016) and service-oriented sectors (Waterbury and Bonilla, 2008) through case studies. However, in the manufacturing sectors, few studies were found.

- The framework behaves differently when applied to companies within developed and developing economies because of differences in infrastructure development and availability of technological resources (Mathur et al., 2012). There are large differences between the two types of economies, during adoption of the LM frameworks with regard to governmental policies, implementation and enforcement of the policies, worker health and safety rules and regulations and their enforcement.

- In cases where the company only produces for local consumers, the situation may be different from global market companies with more strict expectations in products and services and in worker health and safety. Hence, it is necessary to develop country economy -specific frameworks rather than proposing generalised frameworks reported in the reviewed, LM literature.

Based on these gaps, it is clear that there is an urgent need for a framework and for a process by which company leaders can quantify the weights of LM drivers and can build upon the inter-relationships among the drivers. That framework should address aspects such as quality management practices, manufacturing processes and practices, worker health and safety, customer satisfaction, environmental impacts of all dimensions of the supply chain, of the customer usage of the products and of the 'end-of-life' management of the products.

Hence, this clearly supports the objective of the authors of this paper to develop a useful and effective framework for systematically and consistently implementing LM in manufacturing companies.

\section{The Research Flow and Adopted Methodology}

It is essential to have a structured methodology to perform effective research. Similarly, it is necessary to ensure that the research methods used in the study are justified for their applicability. The authors used a hybrid FAHP-DEMATEL approach to achieve the defined 
objectives. Accordingly, this section presents research flow and discusses the adopted methodologies in subsequent sub sections.

\subsection{The Research Flow Adopted for the Study}

The LM drivers reported by various researchers were tabulated and were presented to a panel of experts for their evaluations and recommendations. After, their finalisation of drivers, the experts were asked to categorise them under different groups and to provide the initial inputs for the fuzzy AHP and DEMATEL approach. The fuzzy AHP approach was used to compute the LM driver weights and DEMATEL was utilised to help the researchers identify cause and effect drivers and to investigate the inter-relationships among them. Figure 1 presents the research flow adopted for the research.

[Figure 1 about here]

\subsection{Fuzzy Analytical Hierarchy Process (FAHP)}

Under the umbrella of multi-criteria decision-making approaches; there are several weight computation approaches that can be used, such as the simple multi-attribute rating technique, and the step-wise assessment ratio analysis, Simos etc. (Yadav et al., 2018). Although, there are several decision-making tools, the analytical hierarchy approach has emerged as the preferred choice of researchers, as observed from the literature. It was reported by Thomas Saaty (Saaty, 1981), to be a widely adopted approach. Later, the analytical hierarchy approach was integrated with fuzzy set theory to improve the precision of the solutions. The authors of this paper utilised the paired comparisons made by the experts and further checked its consistency to ensure quality inputs for computation of the weights of the drivers. The detailed procedure for these steps is explained in the following sections.

(1) Identification and finalisation of LM drivers: This step involved the identification of LM drivers. Additionally, an expert panel was formed to obtain inputs for FAHP. The experts were asked to finalise the LM drivers that influenced its adoption. Once the LM drivers were finalised for inclusion within the framework development process, the experts were requested to group the drivers into groups with similarities in function.

(2) Construct paired comparisons: This step used the input of data of paired comparisons from the decisions made by the experts. During this phase, all LM drivers of a particular group were compared together according to the scale presented in Table 2. 
Conduct an exhaustive literature review to explore the existing lean manufacturing frameworks

Identify the key drivers that facilitate implementation of lean manufacturing framework for manufacturing organisations in the context of developing economies

Assemble an expert panel to evaluate and categorise the identified drivers among six major groups and the related sub-groups and prepare inputs for pairwise comparisons

Apply the fuzzy Analytical Hierarchy Approach to compute the weights and consistency check of major and sub-groups of lean manufacturing drivers

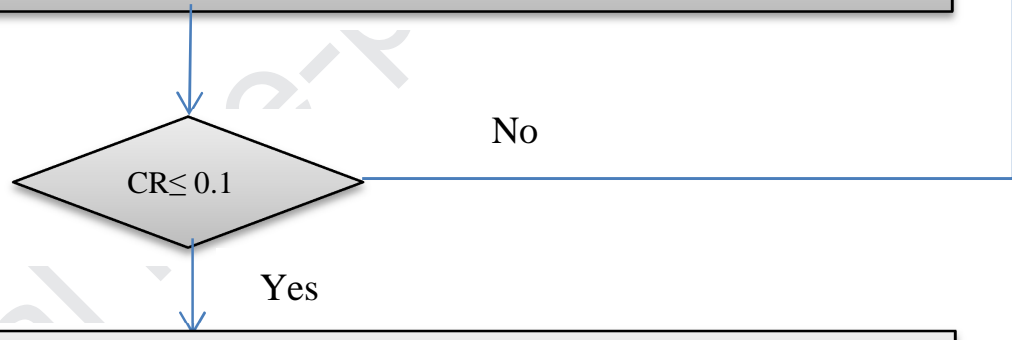

Apply Decision Making Trial and Evaluation Laboratory approach to compute the cause and effect lean manufacturing drivers for initial development

After assessing the threshold values, construct the relationship diagram for major and subgroup lean manufacturing drivers

Propose the lean manufacturing driver based framework for developing economies by addressing the relationships of major group drivers

Share the developed framework with the case organisation and map before and after performance to validate the developed framework

Discuss the findings and present the implications of this study for researchers and practitioners and future scope

Figure 1: Research flow adopted for this research. 
Table 2: Relative importance of the drivers in supporting implementation of LM

\begin{tabular}{l|c|c}
\hline Intensity & Fuzzy Allocation & Corresponding Function \\
\hline Equally Important & $\tilde{1}$ & $(1,1,3)$ \\
\hline Weakly Important & $\tilde{3}$ & $(1,3,5)$ \\
\hline Strongly Important & $\tilde{5}$ & $(3,5,7)$ \\
\hline Very Strongly Important & $\tilde{7}$ & $(5,7,9)$ \\
\hline Extremely Strongly Important & $\tilde{9}$ & $(7,9,11)$ \\
\hline
\end{tabular}

(1) The experts were asked to rate the comparisons among every two drivers, in such a way, that it critically defined how much a particular driver influences the other driver in the pair.

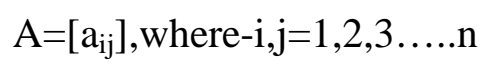

(2) Compute the Eigen values: Each matrix was then processed by computing the Eigen values through each paired comparison matrix. It is important to highlight that for each $n^{*} n$ matrix, there will be $\mathrm{n}$ Eigen values. However, for further calculations the maximum value of those Eigen values was considered.

(3) Consistency check: Once the Eigen values for a particular matrix were obtained, they were utilised for checking the consistency of the particular matrix. Once the matrix was found to be consistent, then it was forwarded for calculation of the driver weights. The Consistency Ratio (CR) was the measure which, was used to check the consistency. It basically refers to the ratio of consistency index to the random index (see Table 3 ) for that particular matrix. For a matrix to be consistent its CR value should be less than 0.1 .

Table 3: Random Consistency Index

\begin{tabular}{c|c|c|c|c|c|c|c|c}
\hline Size (n) & 1 & 2 & 3 & 4 & 5 & 6 & 7 & 8 \\
\hline Random Index (RI) & 0 & 0 & 0.52 & 0.89 & 1.11 & 1.25 & 1.35 & 1.40 \\
\hline
\end{tabular}

(4) Compute the consistency index- The consistency ratio requires availability of a consistency index. A consistency index is the ratio of the difference between the maximum Eigen value and $\mathrm{n}$, with one less value then $\mathrm{n}$. The consistency index tends to be important because it assists in computing the driver's consistency.

\subsection{Decision Making Trial and Evaluation Laboratory (DEMATEL)}

The DEMATEL approach is one of the most commonly used research methods in the MCDM domain (Tzeng et al., 2007). This approach is a well-known problem solving technique that is 
utilised for analysing complex problems (Mehregan et al., 2014; Uygun et al., 2014). This tool basically helps in analysing the factors of the problems within two different groups, namely; the cause group and the effect group (Malekzadeh et al., 2016; Su et al., 2016). The grouping of factors stated above helps the company leaders and researchers to have a better visualisation of their behaviour (Abdullah and Zulkifli, 2015; $\operatorname{Rad}$ et al., 2017). When compared to other modelling approaches (Analytical Network Process (ANP), Total Interpretive Structural Modelling (TISM), and Graph Theory and Matrix Approach (GTMA) etc.), this approach assists the researchers in understanding the contextual relations among the included factors within the problem structure and helps in identifying the strength of their inter-relationships (Gwo-Hshiung and Jih-Jang Huang, 2010).

(1) Develop the Initial Direct Reachability Matrix (IDRM) and the average matrix: This step helps in developing the IDRM and the average matrix. IDRM refers to initial direct reachability matrix. For the rating purpose, the experts were asked to rate the drivers based on their intensity of influence. Here the comparison was made when allotting the influence of one driver over the other. The average direct-relation matrix $\mathrm{M}$ was calculated by utilising (Eq.2).

$$
\mathrm{m}_{\mathrm{ij}}=\frac{1}{H} \sum_{K=1}^{H} x_{i j}^{k}
$$

(2) Compute the normalised matrix: The average matrix developed in previous step was utilised to develop the normalised matrix by utilising (Eq.3).

$$
\mathrm{D}=\mathrm{M} * \mathrm{~S}
$$

$$
\text { Here, S represents }=\min \left[\frac{1}{\max \sum_{j=1}^{n}\left|m_{i j}\right|}, \frac{1}{\max \sum_{i=1}^{n}\left|m_{i j}\right|}\right]
$$

(3) Construct total relation matrix: Once the normalised matrix was obtained, then finally, a total relation matrix was constructed. The final relation matrix is represented by $\mathrm{T}$ and computed by (Eq.4)

$$
\mathrm{T}=\mathrm{D}(\mathrm{I}-\mathrm{D})^{-1}
$$

In Eq.4 the "I" designates the identity matrix. Once the total relation matrix is developed, all the rows and columns are added. The row sum indicates the direct and indirect influence of one LM on all the other drivers. Whereas, the column sum defines the direct and indirect 
influence of one LM driver through all other remaining drivers. Then, " $r_{i}+c j$ " and " $r_{i}-c_{j}$ " were calculated. Here, " $r_{i}+c j$ " represents the total effects that a LM driver has on other drivers and what effects it receives from all other drivers. The formula, " $r_{i}-c_{j}$ " represents the net impacts which the LM driver puts on the entire system. All the LM drivers occurring in " $r_{i}+c j$ " were considered as cause group drivers whereas, all the drivers occurring in " $r_{i}-c_{j}$ " were considered as effect group drivers.

(4) Diagnose threshold value: The threshold value was identified through the total direct relation matrix. The threshold value was calculated by taking the average of all the values of total relation matrix. The threshold value helps in diagnosing the direct and indirect effects of a particular LM driver on the entire system. All the values that were greater than the threshold value indicated the impact of LM driver on the particular driver as well as upon the entire system. All values greater than threshold indicate the relationship of criterion A with criterion $\mathrm{B}$. If only $\mathrm{i}, \mathrm{j}$ or $\mathrm{j}, \mathrm{i}$ entry is greater than threshold then there is a unidirectional relationship among the selected factors. If both $\mathrm{i}, \mathrm{j}$ and $\mathrm{j}, \mathrm{i}$ entries are greater than threshold then there is a bi-directional relationship among the selected factors. The outcomes of threshold value calculations helped in developing the relationship diagram.

The combination of fuzzy AHP-DEMATEL adopted in this research, not only helped in identifying the intensity of influence of each LM driver during the adoption process but also predicted the inter-relations among them in their anticipated behaviour during the LM adoption process. As discussed earlier, there are several techniques to assess the criteria weights but FAHP has an advantage over other MCDM techniques because it compares all the criteria individually and inclusion of fuzzy set theory effectively handles the vagueness among the experts' judgements. Although, many techniques were reported in the reviewed literature to assess the interactions among drivers, DEMATEL can be used to effectively document the interactions among LM drivers spread over different groups which, are often very complex and might affect the final results.

\section{Framework Development and its Testing}

This section presents the framework development and its testing within the case company. Initially, the problem definition and organisation description was explained. Further, the 
expert panel was formed and a framework was developed. Finally, fuzzy AHP and DEMATEL were applied to compute the weights and inter- relationships among the selected drivers. The details are presented in subsequent subsections.

\subsection{Problem Definition and Organisation Description}

To test the applicability of the developed framework, a pump parts manufacturing organisation was selected. It is a private firm which is classified as Indian Non-Government company that manufactures different types and different sizes of motor parts and a sub supplier of pump manufacturing company. The annual turnover of the organisation is 55 million Indian rupees (approximately US\$ 0.8 million). It has approximately 180 employees. The organisation produces Die cast Rotors, Machining Motor Shafts, Machining Die Cast Rotors, Machining Threading Shafts, Machining Motor Shafts Housing, Machining ING Motor Stator Housings, Machining end Shields, Machining Flanges, Machining Rotor with Shafts and many more. The company is equipped with machining facilities such as moulding machines, milling machines, extrusion machines, lathe machines, hydraulic machines, drilling machines, CNC machines, grinding machines etc. The company consists of seven sections namely; foundry section, stator housing section, ES and flange section, stamping section, rotor with shaft section, die casting section, and assembly section.

Before LM implementation, the case company was struggling with defects in their products and facing continuous pressure from its major customer to reduce defects. The company was working on continuous improvement activities but was constantly facing the occurrence of non-value adding activities and generated several wastes within their production processes, which stimulated them to adopt the LM framework as a solution to their inefficiency problems. However, it is important to note that the initial adoption cost of LM was high; so, they wanted to ensure its applicability in their company. Therefore, with these expectations, they agreed to test the LM framework proposed by the authors of this paper, within their company. The proposed LM framework was introduced and implemented during July 2017 and the resultant improvements were documented in July 2018.

\subsection{Panel Formation and Framework Development}

A decision panel, contained a group of six experts, was formed. The selected experts had more than ten years of experience and exposure to LM. Two experts were from the production and design department (senior engineers from the selected case company's major customer), two were from top management, one was from the R \& D department and one was 
from the warehouse and packaging. LM is considered to be a well-proven methodology for improving the organizational performance of manufacturing industries of large, medium as well as small scale organizations. Hence, any framework developed by the researchers/practitioners should hold its applicability across all types of organizations. Hence, in this study, the selection of experts for framework development process has been done keeping the above-mentioned criterion in mind.

The data collection from the experts was performed with the inputs from two brainstorming sessions. First morning session is conducted to finalise the criteria to be chosen for the framework development. The exhaustive list of LM drivers was provided to the experts to finalise the final list of drivers based on their suitability for facilitating the LM adoption across SMEs of developing economies. Later, the experts were asked to group the drivers with similar behaviour. The experts categorised the selected LM drivers into six different aspects of the company namely: the shop floor management, the manufacturing strategies, the quality management, the manufacturing processes, the supplier and customer management, and the work force management, to develop a LM framework to enhance its adoption as shown in Figure 2.

[Figure 2 about here]

This session helped in obtaining the four levels of the LM framework. The Level 1, Level 2, and Level 3 are the three levels of the framework where Level 1 represents the objective of the framework; Level 2 represents major group of drivers; Level 3 represents the sub group drivers of each major group of drivers. The second session was conducted to obtain the inputs for hybrid fuzzy AHP-DEMATEL approach. In fuzzy AHP, the pairwise comparison of drivers of each group were recorded for computing the driver weights; whereas, the comparisons made for DEMATEL approach were utilised to compute the inter-relationships among the drivers included for the LM framework development process. To test this framework, the expert's decisions were utilised for paired comparisons of LM drivers to compute their weights through the fuzzy AHP approach and later to identify the interrelationships among them through the DEMATEL approach. 


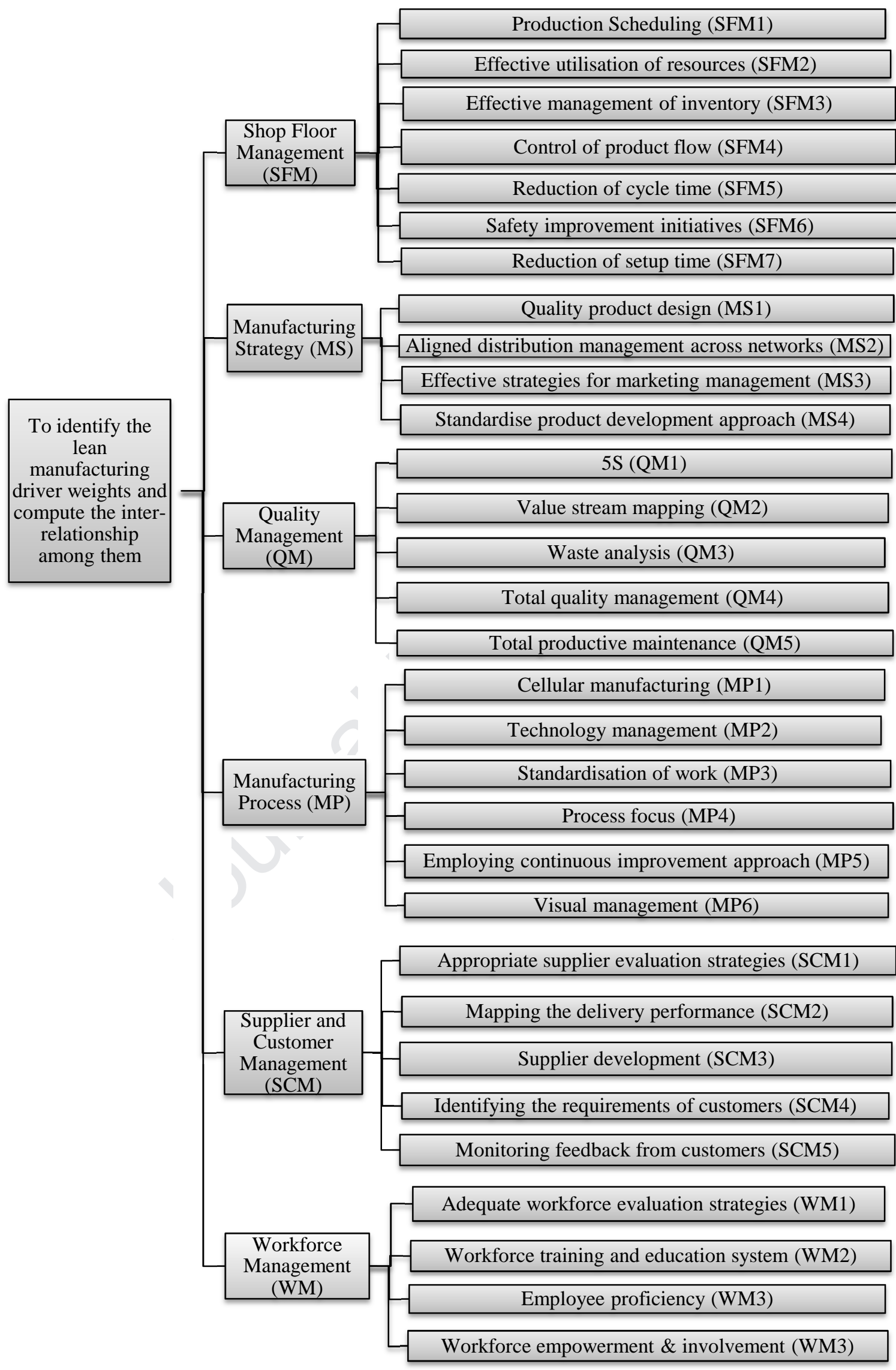

Figure 2: Framework developed for lean manufacturing adoption 


\subsection{Application of Fuzzy AHP}

For computing the weights of LM drivers scrutinised for present research work, fuzzy AHP approach was utilised in this section. As discussed in previous the section, the pairwise comparisons were taken from the experts for the group being developed as shown in Table 1. Based on the feedback from the experts, comparisons of the main criteria drivers and subcriteria drivers were developed. Sub-criteria drivers included shop floor management, manufacturing strategy, quality management, manufacturing process, supplier and customer management and work force management drivers. The detailed comparisons made by the experts for the main criteria were included in Table 4.

Table 4: Paired comparison of main criteria drivers

\begin{tabular}{l|c|c|c|c|c|c|c}
\hline Main drivers & SFM & MS & QM & MP & SCM & WM & Weights \\
\hline Shop Floor Management (SFM) & 1 & 3 & 1 & 3 & 5 & 3 & 0.2969 \\
\hline Manufacturing Strategy (MS) & $1 / 3$ & 1 & 1 & 3 & 5 & 3 & 0.2097 \\
\hline Quality Management (QM) & 1 & 1 & 1 & 3 & 5 & 3 & 0.2409 \\
\hline Manufacturing Process (MP) & $1 / 3$ & $1 / 3$ & $1 / 3$ & 1 & 5 & 3 & 0.1344 \\
\hline Supplier \& Customer Management (SCM) & $1 / 5$ & $1 / 5$ & $1 / 5$ & $1 / 5$ & 1 & 1 & 0.0478 \\
\hline Workforce Management (WM) & $1 / 3$ & $1 / 3$ & $1 / 3$ & $1 / 3$ & 1 & 1 & 0.0704 \\
\hline$\lambda_{\text {max }}=6.5505$, CR=0.088 & & & & &
\end{tabular}

After obtaining decisions from the experts, the standard procedure discussed in the previous section (research methodology) was followed. Each matrix comparison made by the experts was checked for consistency. Initially, the $\lambda_{\max }$ and consistency index was calculated and later its consistency index CI was checked. Only those matrices with a CI value that were less than 0.1 were included for weight calculation purposes. If any matrix was found to be inconsistent then it was again taken to the experts for their opinion (Yadav et al., 2018b; Yadav and Desai, 2017b).

In the present case, all the matrix comparisons made by the experts were found to be consistent. Once the weights of the main and sub-criteria were achieved their global weights were calculated as shown in Table 5.

Table 5: Weights of lean management drivers

\begin{tabular}{l|l|c|c|c|c|c}
\hline Main Criteria drivers & $\begin{array}{l}\text { Main } \\
\text { Criteria } \\
\text { Weight }\end{array}$ & Sub-driver code & $\begin{array}{c}\text { Consistency } \\
\text { ratio }\end{array}$ & $\begin{array}{c}\text { Local } \\
\text { weight }\end{array}$ & $\begin{array}{c}\text { Global } \\
\text { Weight }\end{array}$ & Rank \\
\hline $\begin{array}{l}\text { Shop floor management } \\
\text { (SFM) }\end{array}$ & 0.296 & SFM1 & 0.067 & 0.1468 & 0.0436 & 9 \\
\cline { 5 - 7 } \cline { 5 - 7 } & & SFM2 & & 0.0397 & 0.0118 & 25 \\
\hline
\end{tabular}




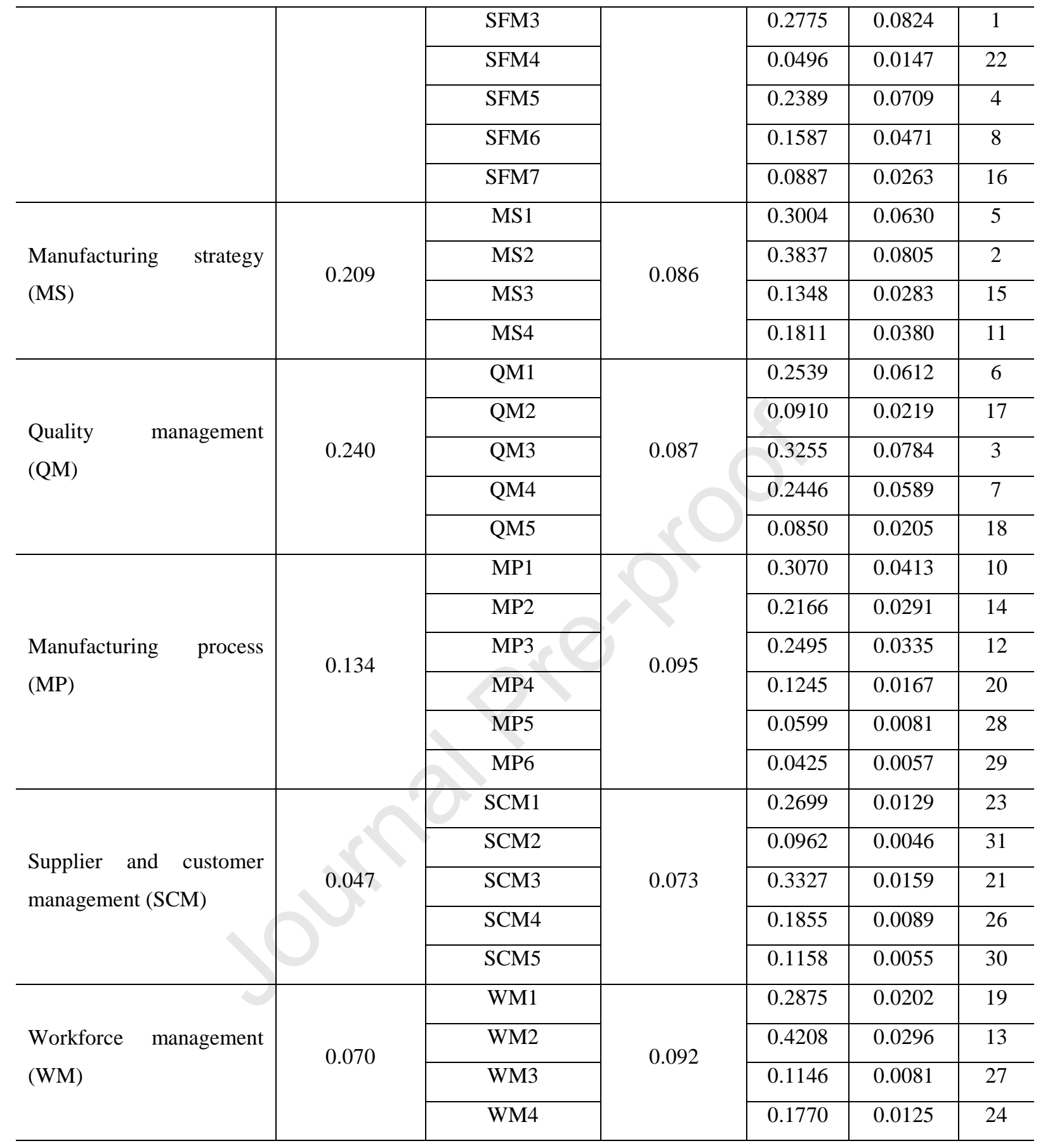

\subsection{Application of DEMATEL}

After calculating the weights of all included drivers, the next stage was to compute their relationships and their cause and effect intensities. For this purpose, the standard DEMATEL approach was utilised as discussed in the previous section. As done in computing the driver weights, the experts were again asked to make the relationship comparisons of the drivers. Each expert was asked to make separate comparisons and later an average direct relationship matrix (Table 6) was developed by taking mean of all the judgements made by the experts for all the comparisons separately. 
Table 6: Average direct relation matrix of main criteria drivers

\begin{tabular}{l|l|l|l|l|l|l}
\hline Drivers & SFM & MS & QM & MP & SCM & WM \\
\hline SFM & 0 & 2.8 & 3.4 & 2.8 & 2.6 & 3.4 \\
\hline MS & 1.8 & 0 & 3 & 3.4 & 2.4 & 1.8 \\
\hline QM & 3.2 & 2.8 & 0 & 2.4 & 2.8 & 3.2 \\
\hline MP & 2.2 & 2.2 & 3 & 0 & 2.4 & 1.8 \\
\hline SCM & 2.8 & 2.2 & 1.8 & 1.6 & 0 & 1.6 \\
\hline WM & 2.6 & 1.6 & 2 & 1.6 & 1.6 & 0 \\
\hline
\end{tabular}

Further, with the help of the average direct relation matrix, a normalised direct relation matrix (Table 7) was developed for the drivers across all categories.

Table 7: Normalised direct relation matrix of main criteria drivers

\begin{tabular}{l|c|c|c|c|c|c}
\hline Drivers & SFM & MS & QM & MP & SCM & WM \\
\hline SFM & 0 & 0.186 & 0.226 & 0.186 & 0.173 & 0.226 \\
\hline MS & 0.12 & 0 & 0.2 & 0.226 & 0.16 & 0.12 \\
\hline QM & 0.213 & 0.186 & 0 & 0.16 & 0.186 & 0.213 \\
\hline MP & 0.146 & 0.146 & 0.2 & 0 & 0.16 & 0.12 \\
\hline SCM & 0.186 & 0.146 & 0.12 & 0.106 & 0 & 0.106 \\
\hline WM & 0.173 & 0.106 & 0.133 & 0.106 & 0.106 & 0 \\
\hline
\end{tabular}

Consequently, by following the standard procedure described in the previous section, the total relations and direct-indirect relationships (Table 8) that were the $r_{i}$ and $c_{j}$ values for all the comparisons was used.

Table 8: Total relation and direct-indirect relation matrix of main criteria drivers

\begin{tabular}{l|l|l|l|l|l|l|l|l|l}
\hline Drivers & SFM & MS & QM & MP & SCM & $\mathbf{W M}$ & $\mathbf{r}_{\mathbf{i}}$ & $\mathbf{r}_{\mathbf{i}}+\mathbf{c}_{\mathbf{j}}$ & $\mathbf{r}_{\mathbf{i}}-\mathbf{c}_{\mathbf{j}}$ \\
\hline SFM & 0.748 & 0.852 & 0.960 & 0.860 & 0.852 & 0.897 & 5.170 & 9.640 & 0.699 \\
\hline MS & 0.745 & 0.594 & 0.829 & 0.788 & 0.741 & 0.710 & 4.406 & 8.569 & 0.242 \\
\hline QM & 0.898 & 0.829 & 0.748 & 0.817 & 0.837 & 0.863 & 4.992 & 9.633 & 0.351 \\
\hline MP & 0.734 & 0.693 & 0.796 & 0.570 & 0.711 & 0.684 & 4.188 & 8.398 & -0.023 \\
\hline SCM & 0.691 & 0.627 & 0.664 & 0.603 & 0.505 & 0.607 & 3.697 & 7.917 & -0.524 \\
\hline WM & 0.654 & 0.569 & 0.644 & 0.574 & 0.575 & 0.484 & 3.499 & 7.744 & -0.746 \\
\hline Sum $\mathbf{c}_{\mathbf{j}}$ & 4.471 & 4.163 & 4.641 & 4.210 & 4.220 & 4.245 & Threshold value $=0.721$ \\
\hline
\end{tabular}

Note: The italic values in the table indicate the relations greater than threshold values 


\section{The Research Study Findings}

All the $(r+c)$ values were taken on the $y$-axis whereas the $(r-c)$ values were taken on the $x$ axis. The threshold value represents the mean value of all the final values obtained in the total relation and direct-indirect matrix. All the values above the threshold values have influence on the other driver. If any comparison in total relation and direct-indirect matrix appeared to be more than threshold value then it represented mutual relationships among both LM drivers. All the drivers above the $\mathrm{x}$-axis were causal drivers and the drivers that were below the $\mathrm{x}$-axis were effect drivers. The second phase in the figure represents the interrelationships of each driver with the others.

The causal digraph and relationship diagram for main criteria drivers were shown in Figure 3.
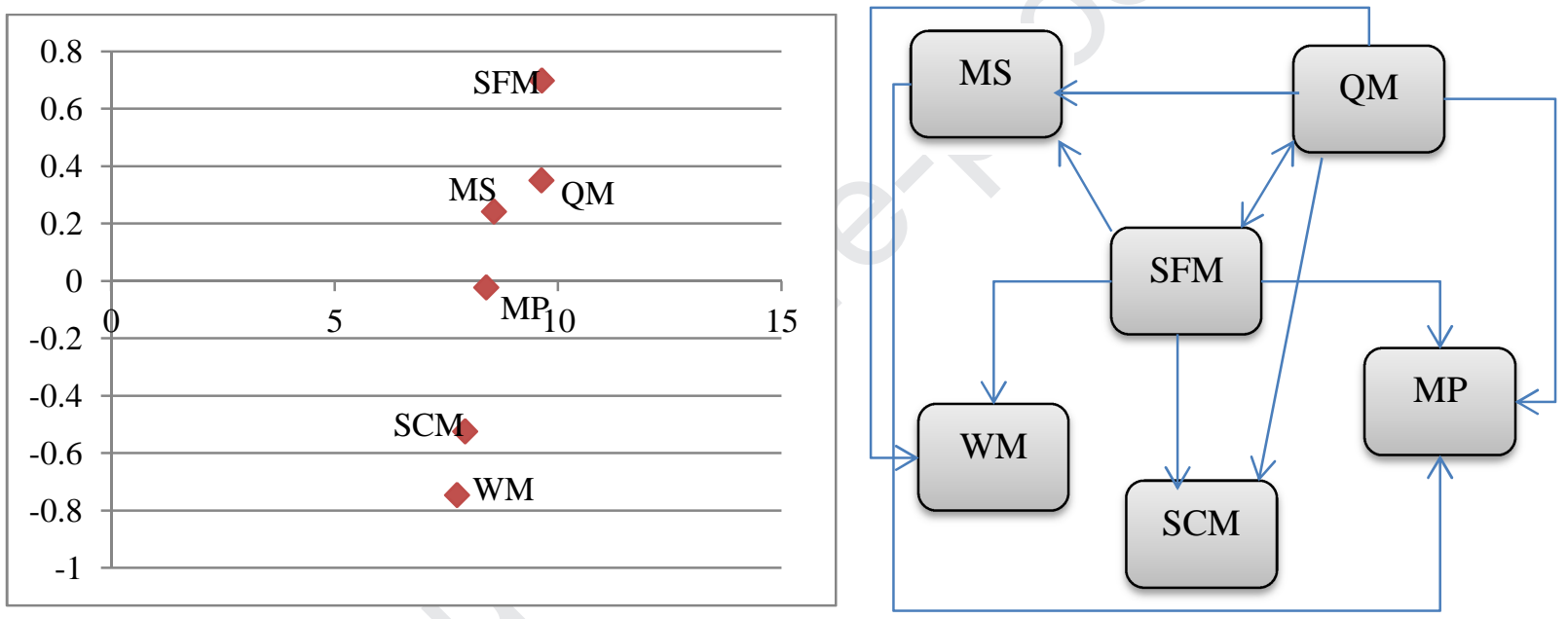

Figure 3: Causal digraph and relationship diagram for main criteria drivers

The results revealed that shop floor management, manufacturing strategies and quality management were the cause drivers whereas, the manufacturing process, supplier and customer management, and work force management were found to be effect drivers which, were later developed by successful penetration of causal drivers. The shop floor management supports the development of all other drivers similar to manufacturing strategy and quality management.

However, work force management and supplier and customer management were completely dependent upon other cause drivers. It was found within the case organisation that the management was struggling to achieve effective supplier and customer management. Hence, the management directly concluded from Figure 3, that the shop floor management and quality management had strong influence on SCM. 
By adopting the suggested framework, the customer complaints/returns were reduced by 6.6 percent (212 to 198 complaints per year) (Table 9). This is consistent with the findings of Drohomeretski et al. (2014) who underscored the importance of involvement of shop-floor management personnel in enhancing LM adoption.

Table 9: Performance metrics mapped in the case company

\begin{tabular}{|c|c|c|c|c|c|}
\hline $\begin{array}{l}\text { S. } \\
\text { No. }\end{array}$ & $\begin{array}{l}\text { Performance } \\
\text { metrics }\end{array}$ & Description & $\begin{array}{l}\text { July } 2017 \\
\text { (Before } \\
\text { LM } \\
\text { adoption) }\end{array}$ & $\begin{array}{l}\text { July } 2018 \\
\text { (After LM } \\
\text { adoption) }\end{array}$ & $\begin{array}{l}\text { Percentage } \\
\text { change }\end{array}$ \\
\hline 1 & $\begin{array}{l}\text { Manufacturing } \\
\text { cycle time }\end{array}$ & $\begin{array}{l}\text { It was the total time taken from } \\
\text { beginning of manufacturing process to } \\
\text { obtain a finished product }\end{array}$ & 114 hours & 106 hours & $\begin{array}{l}7 \% \\
\text { reduction }\end{array}$ \\
\hline 2 & Changeover time & $\begin{array}{l}\text { It was the time measured by the process } \\
\text { that maps the converting of } \\
\text { line/machine from one part to the other }\end{array}$ & 85 seconds & 80 seconds & $\begin{array}{l}5.9 \% \\
\text { reduction }\end{array}$ \\
\hline 3 & Throughput & $\begin{array}{l}\text { It indicated the average number of parts } \\
\text { produced over a specific period of time }\end{array}$ & $\begin{array}{l}4824 \text { pieces } \\
\text { per month }\end{array}$ & $\begin{array}{l}4935 \text { pieces } \\
\text { per month }\end{array}$ & $\begin{array}{l}2.3 \% \\
\text { increase }\end{array}$ \\
\hline 4 & $\begin{array}{l}\text { Overall equipment } \\
\text { effectiveness }\end{array}$ & $\begin{array}{l}\text { Overall equipment effectiveness } \\
\text { represents the effectiveness of the } \\
\text { entire production line }\end{array}$ & 88 percent & 91 percent & $\begin{array}{l}3.7 \% \\
\text { increase }\end{array}$ \\
\hline 5 & $\begin{array}{l}\text { Planned } \\
\text { maintenance } \\
\text { percentage }\end{array}$ & $\begin{array}{l}\text { Total number of planned maintenance } \\
\text { times spent on the defined activities for } \\
\text { a given period of time. }\end{array}$ & 75 percent & 81 percent & $\begin{array}{l}8.4 \% \\
\text { increase }\end{array}$ \\
\hline 6 & First pass yield & $\begin{array}{l}\text { It indicates the percentage of products } \\
\text { manufactured accurately in the very } \\
\text { first time (no rework, no re-run) }\end{array}$ & $\begin{array}{l}1035 \text { pieces } \\
\text { per week }\end{array}$ & $\begin{array}{l}1081 \text { pieces } \\
\text { per week }\end{array}$ & $\begin{array}{l}4.4 \% \\
\text { increase }\end{array}$ \\
\hline 7 & Overall yield & $\begin{array}{l}\text { It indicates the percentage of products } \\
\text { that may or may not require reworking } \\
\text { to meet the desired specifications }\end{array}$ & $\begin{array}{l}1125 \text { pieces } \\
\text { per week }\end{array}$ & $\begin{array}{l}1151 \text { pieces } \\
\text { per week }\end{array}$ & $\begin{array}{l}2.3 \% \\
\text { increase }\end{array}$ \\
\hline 8 & $\begin{array}{l}\text { Customer } \\
\text { return/complaint }\end{array}$ & $\begin{array}{l}\text { It represents the number of } \\
\text { malfunctioning products that were } \\
\text { returned }\end{array}$ & $\begin{array}{l}212 \text { pieces } \\
\text { per year }\end{array}$ & $\begin{array}{l}198 \text { pieces } \\
\text { per year }\end{array}$ & $\begin{array}{l}6.6 \% \\
\text { reduction }\end{array}$ \\
\hline 9 & $\begin{array}{l}\text { Supplier defect } \\
\text { rate }\end{array}$ & $\begin{array}{l}\text { It indicates the percentage of poor } \\
\text { quality materials received from } \\
\text { suppliers }\end{array}$ & $\begin{array}{l}1.8 \text { percent } \\
\text { lots per } \\
\text { year }\end{array}$ & $\begin{array}{l}1.6 \text { percent } \\
\text { lots per } \\
\text { year }\end{array}$ & $\begin{array}{l}11 \% \\
\text { reduction }\end{array}$ \\
\hline 10 & $\begin{array}{lr}\text { Number } & \text { of } \\
\text { training } & \text { sessions }\end{array}$ & $\begin{array}{l}\text { It indicates the total number of training } \\
\text { sessions conducted for enhancing the }\end{array}$ & $\begin{array}{l}4 \text { training } \\
\text { sessions }\end{array}$ & $\begin{array}{l}6 \text { training } \\
\text { sessions }\end{array}$ & $\begin{array}{l}50 \% \\
\text { increase }\end{array}$ \\
\hline
\end{tabular}




\section{Journal Pre-proof}

\begin{tabular}{|c|c|c|c|c|c|}
\hline & (Every year) & organisational performance & per year & per year & \\
\hline 11 & $\begin{array}{l}\text { Safety metrics } \\
\text { (Every year) }\end{array}$ & $\begin{array}{l}\text { It represents the occurrence of } \\
\text { accidents during production }\end{array}$ & $\begin{array}{l}48 \\
\text { accidents } \\
\text { per year }\end{array}$ & $\begin{array}{l}38 \\
\text { accidents } \\
\text { per year }\end{array}$ & $\begin{array}{l}21 \% \\
\text { reduction }\end{array}$ \\
\hline 12 & $\begin{array}{l}\text { Daily target } \\
\text { achievement rate }\end{array}$ & $\begin{array}{l}\text { It indicates the percent of the target } \\
\text { achieved during each working shift }\end{array}$ & 78 percent & 82 percent & $\begin{array}{l}5.1 \% \\
\text { increase }\end{array}$ \\
\hline 13 & $\begin{array}{l}\text { Net operating } \\
\text { profit }\end{array}$ & $\begin{array}{l}\text { It indicates the net financial profit } \\
\text { accounted by the firm after } \\
\text { consideration of all expenses }\end{array}$ & $\begin{array}{l}12.1 \\
\text { percent per } \\
\text { annum }\end{array}$ & $\begin{array}{l}13.9 \\
\text { percent per } \\
\text { annum }\end{array}$ & $\begin{array}{l}15 \% \\
\text { increase }\end{array}$ \\
\hline 14 & On time delivery & $\begin{array}{l}\text { It indicates the percentage of on time } \\
\text { deliveries to the customers }\end{array}$ & 91 percent & 94 percent & $\begin{array}{l}3.2 \% \\
\text { increase }\end{array}$ \\
\hline
\end{tabular}

The causal digraph and relationship diagram for shop floor management drivers were shown in Figure 4.
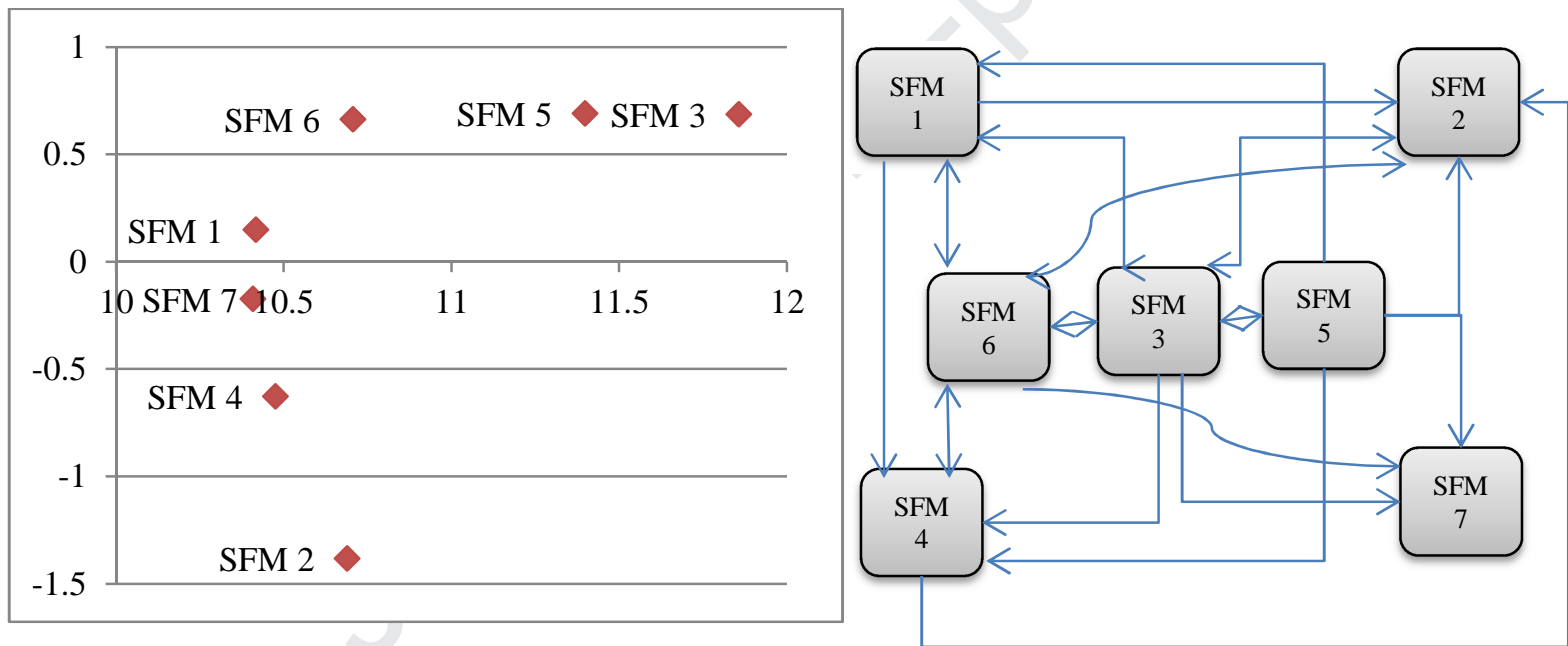

Figure 4: Causal digraph and relationship diagram for shop floor management drivers

The results revealed that there was improved management of the inventory (SFM3), reduction of cycle times (SFM5), improvements in safety from the initiatives implemented (SFM6) and improvements due to enhanced production scheduling (SFM1) which were the cause drivers whereas, effective utilisation of resources (SFM2), control of product flow (SFM4) and reduction of setup times (SFM7) were effect drivers. The relationship diagram shows that the safety improvement initiatives hold mutual relationships with the other subdrivers and reduced the occurrence of accidents on the shop floor by 21 percent (48 to 38 accidents per year).

Effective inventory management was interconnected with all shop floor management activities and it helps in optimal utilisation of available resources on the shop floor. It was 
found that prior to the improvements, that the shop floor supervisors encountered long manufacturing cycle times, while, after adoption of the LM framework their manufacturing cycle times was reduced to 106 hours from 114 hours (Table 9). Thomas et al. (2016) obtained similar significant improvements underscored significance of effective management of inventory in achieving control of product flow and efficient utilisation of resources.

The causal digraph and relationship diagrams for the manufacturing strategy drivers were shown in Figure 5. The results of the causal digraph reveals that quality product design (MS1), aligned distribution management across networks (MS2) and the standardised product development approach (MS4) were cause drivers whereas, an effective strategy for marketing management (MS3) was found to be the most significant effect driver as it depends on the effective execution of other manufacturing strategies. According to relationship diagram, the aligned distribution management emerged as the root cause for the related sub-criteria drivers.
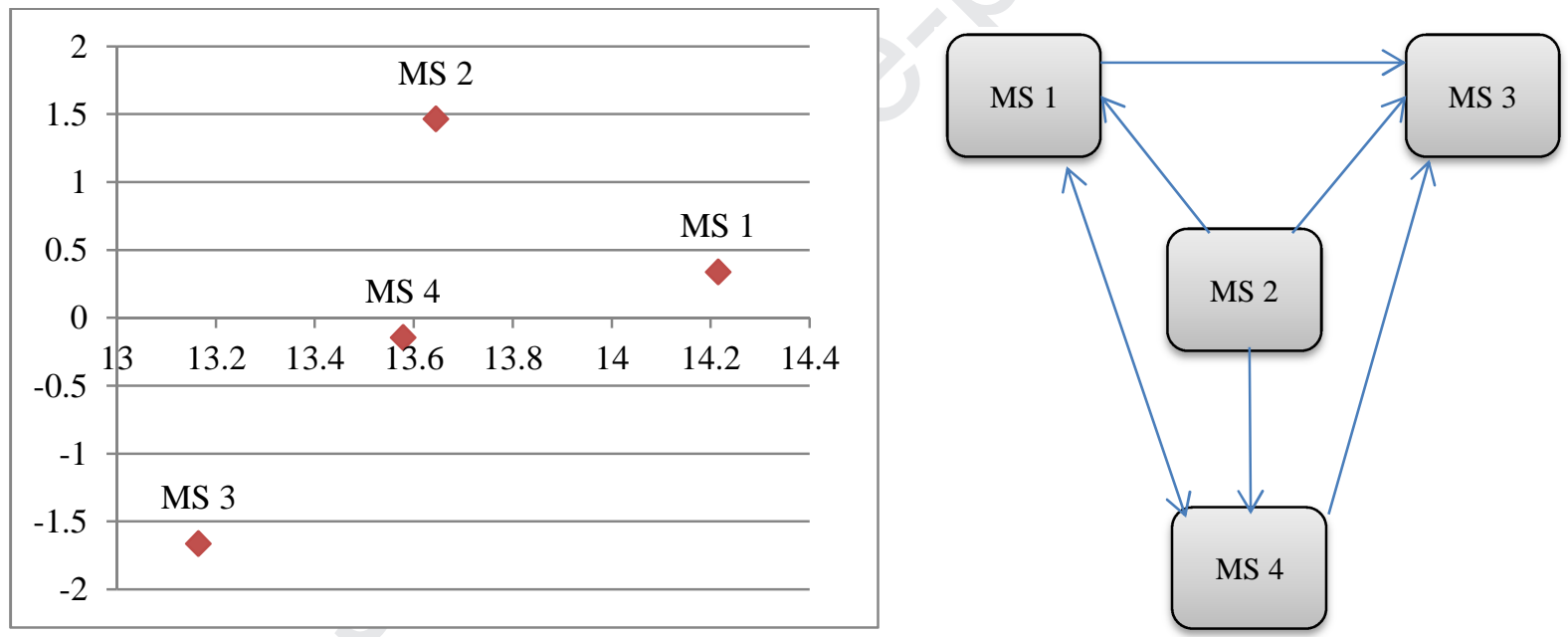

Figure 5: Causal digraph and relationship diagram for manufacturing strategy drivers

It was observed, within the case company, that the production planners were able to reduce the change over time by 5.9 percent and increased the throughput by 2.3 percent after adopting the suggested LM framework. Garza-Reyes et al. (2016) stated that standardised product development approaches lead to improved quality product design and improved distribution management across networks; therefore, their findings are in accord with the findings of this research.

The causal digraph and relationship diagram for quality management drivers were presented Figure 6. 

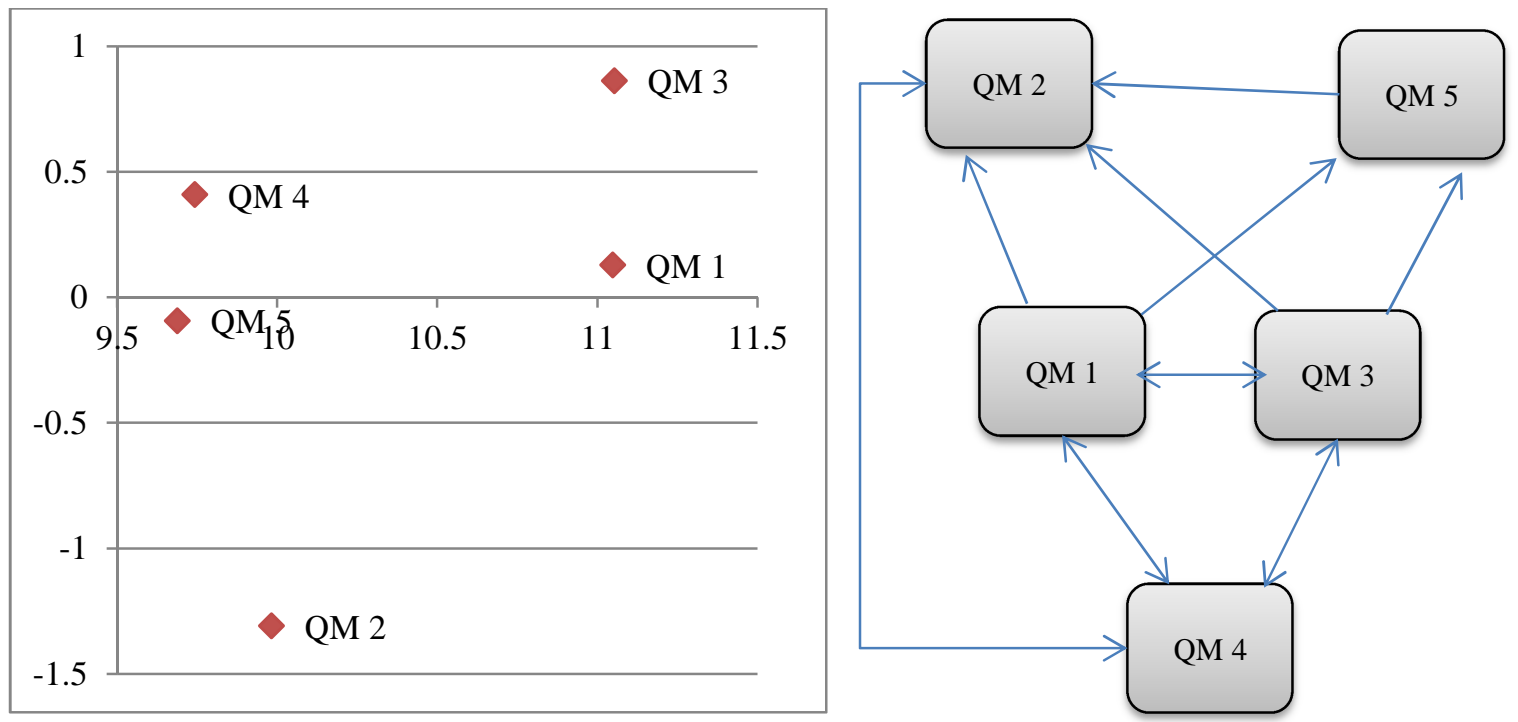

Figure 6: Causal digraph and relationship diagram for quality management drivers

The causal digraph results revealed that 5S (QM1), waste analysis (QM3), total quality management (QM4) and total productive maintenance (QM5) were the cause drivers whereas, value stream mapping (QM2) was found to be the most prominent effect driver. Basically, the implementation of value stream mapping was performed in two stages, where previously the state map was developed which, represented the previous process structure of the organisation but after incorporating the new quality management initiatives, QM1, QM3, QM4 and QM5 the new state map was developed that includes the improvement initiatives.

It was found that $5 \mathrm{~S}$ and waste analysis have strong inter-linkages with other quality management inputs as was clarified in the relationship diagram. This underscores that improved productive maintenance can be successfully executed with the help of 5S, waste analysis and value stream mapping. It was documented within the case organisation that the management initiated the implementation of $5 \mathrm{~S}$, value stream mapping and total productive maintenance and obtained an increase of $8.4 \%$ in planned maintenance percentage and $3.7 \%$ increase in overall equipment effectiveness. These results underscore Duarte and CruzMachado (2009) findings of the importance of implementation of quality management practices as a prerequisite of successful LM adoption.

The causal digraph and the relationship diagram for the manufacturing process drivers were shown in Figure 7. 

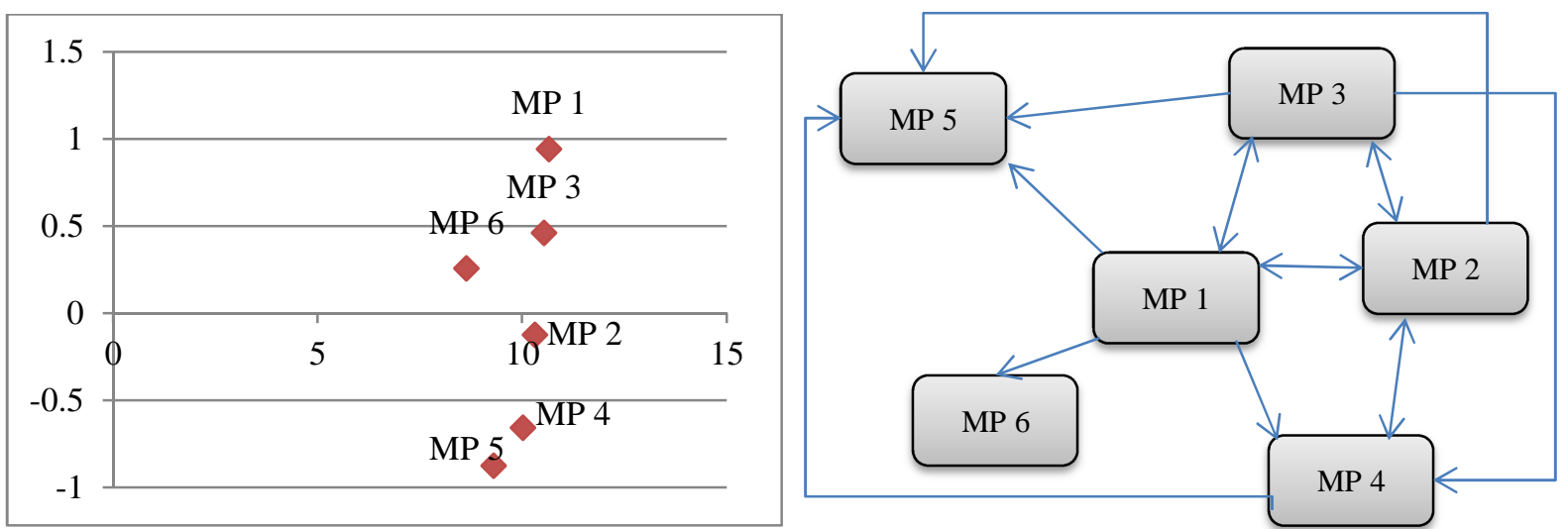

Figure 7: Causal digraph and relationship diagram for manufacturing process drivers

The causal digraph results revealed that cellular manufacturing (MP1), standardisation of work (MP3) and visual management (MP6) were the cause drivers whereas, technology management (MP2), process focus (MP4) and employing continuous improvement approaches (MP6) were found to be the most critical effect drivers. The relationship diagram shows that cellular manufacturing plays a vital role in adopting LM within the organisation under manufacturing process drivers because it supports all other drivers within its subcriteria. Similarly, standardisation of work across each process and machine set-up was essential; hence, it supports all other sub-criteria drivers. It was found within the case company that the manufacturing process strongly influences the performance metrics.

After adoption of the suggested LM framework the first pass yield increased to 4.4 percent, while, the overall yield was increased to 2.3 percent. However, the on-time delivery was increased by 3.2 percent (Table 9). These findings are in agreement with those of Ramos et al. (2018) who reported process focus, continuous improvement and technology management as the essential driver components for LM adoption.

The causal digraph and relationship diagram for supplier and customer management drivers were shown in Figure 8.
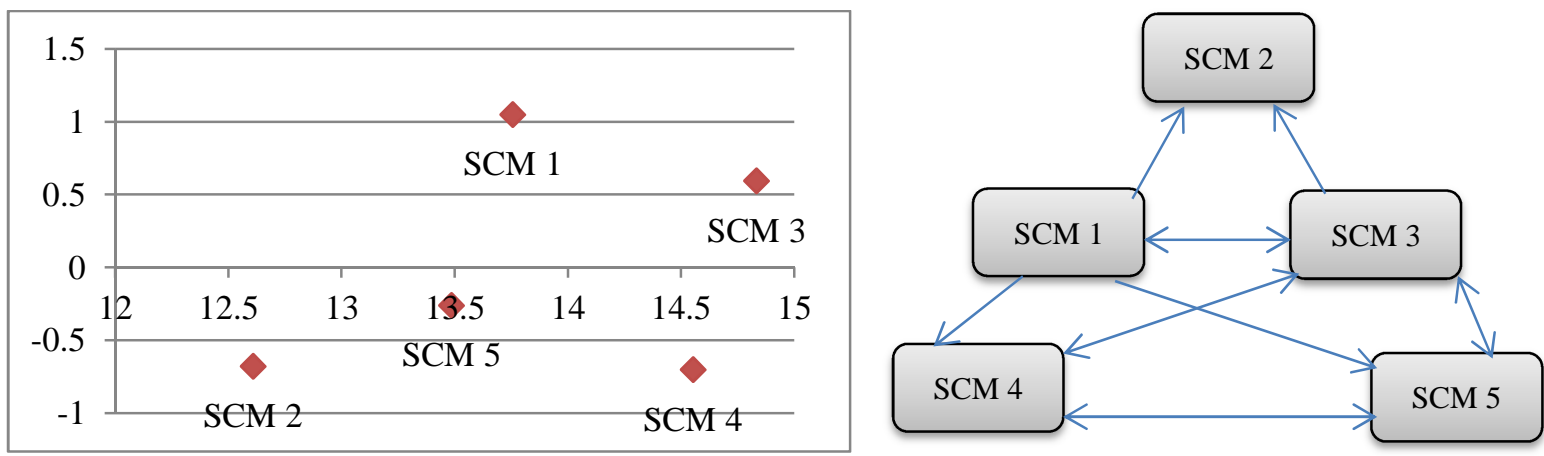

Figure 8: Causal digraph and relationship diagram for supplier and customer management drivers 
The causal digraph results revealed that appropriate supplier evaluation strategies (SCM1) and supplier development (SCM3) were the cause drivers whereas, mapping the delivery performance (SCM2), identifying the requirements of customers (SCM4) and monitoring feedback from customers (SCM5) were observed as the key effect drivers. The relationship diagram shows that appropriate supplier evaluation strategies and supplier development helps in achieving all other sub-criteria drivers whereas, mapping the delivery performance emerged as a strong effect variable, which was highly dependent on other cause drivers.

It was found within the case company that customer returns were reduced to 198 pieces per year $(6.6 \%$ reduction) and supplier defect rate was reduced by $11 \%$ after adoption of the suggested LM framework. This finding is in accord with Henao et als. (2019) who highlighted the importance of mapping of delivery performance, identifying customer requirements and adopting appropriate supplier evaluation strategies to improve supplier coordination and to improve customer satisfaction. Additionally, it helped in achieving daily targets.

The causal digraph and relationship diagram for work force management drivers were shown in Figure 9.
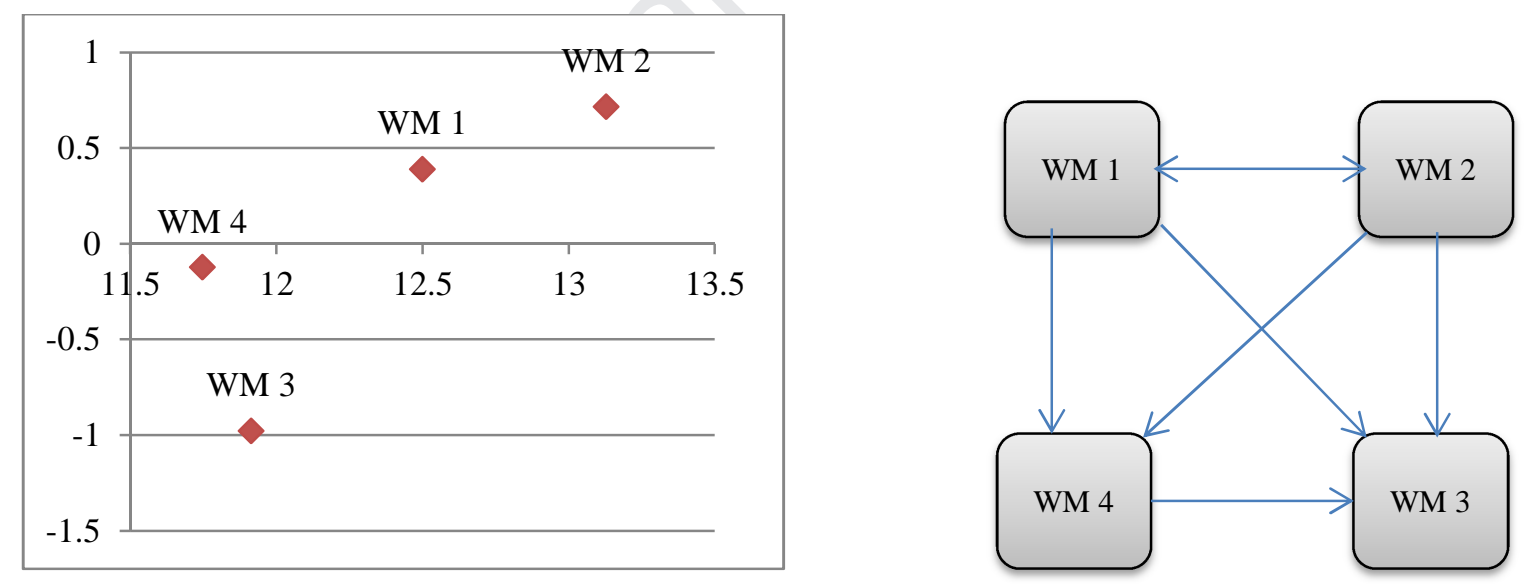

Figure 9: Causal digraph and relationship diagram for workforce drivers

The causal digraph results reveal that good work force evaluation strategies (WM1), work force training and education system (WM2) were the cause drivers whereas, employee proficiency (WM3) and work force empowerment and involvement (WM4) were found to be the most essential effect drivers. The relationship diagram reflects that the findings that employee proficiency was highly dependent on other sub-criteria drivers which, were 
interconnected to successful implementation of other drivers. It was observed within the case company that the workforce management had significant influence in company performance. The framework suggested to them, improved the net operating profits by $15 \%$ and increases in training sessions drastically helped to improve overall performance of the company, which was in accord with the findings of Gandhi et al. (2018) who highlighted the importance of involvement of the workforce in improving operational performance and in achieving the company's goals by using appropriate workforce evaluation strategies, by providing focussed training for LM adoption and by involving them in strategic decision-making.

\section{Implications of the findings of this research}

This research made valuable contributions to the LM domain for company leaders and for researchers in the following ways:

- The authors of this paper utilised a hybrid fuzzy AHP-DEMATEL approach for developing the LM framework for manufacturing companies in the context of emerging economies. It was found from the literature that many researchers had computed LM driver weights but they did not assess the inter-relationships among the drivers. The authors of this paper not only computed the driver weights but also assessed the effects of various drivers upon the others.

- This investigation will help researchers to obtain a comprehensive, driver-based data set that can be utilised for building LM specific frameworks for their companies. The framework developed in this research can support company leaders in planning their strategies for effectively implementing LM by assessing the inter-relationships of LM drivers.

- The researchers in this study initially assessed the existing LM frameworks reported by various authors. The comparison of frameworks developed within the existing frameworks will help to stimulate new research within the academic community and will assist them in developing better LM frameworks that can be used to help leaders of SMEs and large companies to more effectively to implement LM.

- The LM framework developed within this research was applied as a case study within a manufacturing company, which documented improvements in organisational performance across 14 different performance metrics as shown in Table 9. Similar companies can effectively utilise the study outcomes within their companies. 
- The LM framework developed and tested within this study was designed for manufacturing organisations of developing nations. However, the authors recommend that the LM this framework can also be utilised in other industrial sectors in developed countries by modifying the initial inputs with the help of experts of their respective sectors.

- In the future, researchers can broaden and strengthen the set of performance drivers included in this study and can use the framework within different companies to expand and deepen application.

- The researchers of this paper identified a set of thirty-one key LM drivers that included the shop-floor management, the manufacturing strategies, the quality management, the manufacturing processes, the suppliers and customers, and the workforce management, based drivers. The authors documented that much of the previous research on LM drivers, mainly focussed upon managerial aspects as LM drivers. Therefore, this research, with its more holistic and comprehensive perspective and scope provided a broader and deeper foundation for supporting future research and broader implementation of LM in companies in a wide array of industrial sectors and in diverse country contexts.

- In the literature, many of LM frameworks were reported; those were more theoretical and often lacked real world documentation. But, this research was designed and tested via the hybrid fuzzy AHP-DEMATEL approach in a specific company. This increases and strengthens the applicability of the developed framework.

- It is further expected that the outcomes of the developed framework will provide directions to the policy makers for developing policies related to rebates and subsidies to the SMEs on LM adoption because SMEs make strong contribution to the economies of all countries.

\section{Conclusions}

In line with the research objectives, the researchers initially conducted an exhaustive literature review to explore the LM frameworks reported in the literature. The framework components (drivers) were identified and scrutinised, by keeping in mind the context of manufacturing organisations of developing economies. A manufacturing case company was selected to test the developed framework. The expert panel from within the case company 
was formed and their inputs were obtained for using the hybrid fuzzy AHP-DEMATEL approach. The fuzzy AHP approach helped in computing the LM driver weights which, were then used as inputs for the DEMATEL approach. The DEMATEL approach analyses helped in finding the causes and effects of each of the LM drivers and provided insights into the inter-relationships among the drivers via the relationship diagrams.

The research results revealed that the shop floor management manufacturing strategies and the quality management practices were the causal drivers whereas, the manufacturing processes, the supplier and customer management, and the work force management were documented to be the effect drivers. The influence intensity of the shop floor management was higher than the threshold value of the other drivers, which documented its strong influence over the other drivers. The performance of the organisation was mapped after implementing the proposed LM framework in the case organisation for one year. There was a significant increase in the percentage of planned maintenance, overall equipment effectiveness, overall yield and net operating profits. There were significant reductions in manufacturing cycle times, customer complaints and supplier defect rates, and number of accidents.

This research was built upon input from an expert panel comprised of personnel from within the case organisation. However, to make the study more robust, the researchers could conduct a large-scale survey to obtain a more exhaustive list of LM drivers. Although, the present set of drivers was explored by specifically focussing on manufacturing organisations from developing economies, the set of LM drivers should be tested in an array of other sectors in the service industry, the healthcare sector and others. The validation of the developed LM framework was done via a single case study. The researchers can perform multiple case studies in various sub-domains of the manufacturing sector through the developed LM framework, to enrich the application insights. The hybrid fuzzy AHP-DEMATEL approach, utilised in this study, provided a unique balance by assessing the factor weights and computation of the inter-relationships among the selected factors. However, other hierarchical approaches can be used in developing the framework but those methods would not provide the threshold values of each group of factors, which is an essential component to be identified to predict the success of any framework.

If the researchers and company leaders wish to utilise this framework in the context of developed economies, especially in countries like United States, United Kingdom, Germany etc. then it is recommended that they consult with experts within the manufacturing domains of that respective country and accordingly ascertain the inputs for the framework that should 
be modified to obtain the country-specific results. The researchers used the hybrid fuzzy AHP-DEMATEL approach, for this research but other researchers may elect to use other tools such as multi-criteria decision-making approaches to build upon the findings reported in this paper. In order to find the structural comparisons, the researchers may wish to use interpretive structural modelling, fuzzy cognitive maps, analytical network processes etc. for better visualisation of the proposed and tested framework used in this research.

\section{Acknowledgement}

The authors are thankful to the case company and to the members of the expert panel for providing their constructive inputs for the hybrid fuzzy AHP-DEMATEL approach, which was essential in implementing this research.

\section{References}

Abdullah, L., Zulkifli, N., 2015. Integration of fuzzy AHP and interval type-2 fuzzy DEMATEL: An application to human resource management. Expert Syst. Appl. 42, 4397-4409. doi:10.1016/j.eswa.2015.01.021

Alhuraish, I., Robledo, C., Kobi, A., 2017. A comparative exploration of lean manufacturing and six sigma in terms of their critical success factors. J. Clean. Prod. 164, 325-337. doi:10.1016/j.jclepro.2017.06.146

Anvari, A., Zulkifli, N., Sorooshian, S., Boyerhassani, O., 2014. An integrated design methodology based on the use of group AHP-DEA approach for measuring lean tools efficiency with undesirable output. Int. J. Adv. Manuf. Technol. 70, 2169-2186. doi:10.1007/s00170-013-5369-z

Ar, R., 2012. Production Flow Analysis through Value Stream Mapping: A Lean Manufacturing Process Case Study 41, 1727-1734. doi:10.1016/j.proeng.2012.07.375

Azadegan, A., Patel, P.C., Zangoueinezhad, A., Linderman, K., 2013. The effect of environmental complexity and environmental dynamism on lean practices. J. Oper. Manag. 31, 193-212. doi:10.1016/j.jom.2013.03.002

Bamber, L., Dale, B.G., 2000. traditional manufacturing environment Lean production : a study of application in a traditional manufacturing environment. Prod. Plan. Control Manag. Oper. 11, 291-298. doi:10.1080/095372800232252

Bayou, M.E., Korvin, A. De, 2008. Measuring the leanness of manufacturing systems - A case study of Ford Motor Company and General Motors. J. Eng. Technol. Manag. 25, 287-304. doi:10.1016/j.jengtecman.2008.10.003

Belekoukias, I., Garza-reyes, J.A., Kumar, V., 2014. The impact of lean methods and tools on the operational performance of manufacturing organisations. Int. J. Prod. Res. 52, 5346-5366. doi:10.1080/00207543.2014.903348

Bhasin, S., 2013. Impact of corporate culture on the adoption of the Lean principles. Int. J. Lean Six Sigma 4, 118-140. doi:10.1108/20401461311319329

Bhasin, S., 2011a. Improving performance through Lean. Int. J. Manag. Sci. Eng. Manag. 6, 23-36.

Bhasin, S., 2011b. Measuring the Leanness of an organisation. Int. J. Lean Six Sigma 2, 55-74. 
doi:10.1108/20401461111119459

Bhaskaran, E., 2012. Lean Manufacturing Auto Cluster at Chennai 93, 383-390. doi:10.1007/s40032-012-0035Z

Bortolotti, T., Romano, P., 2012. 'Lean first, then automate ': a framework for process improvement in pure service companies. A case study. Prod. Plan. Control Manag. Oper. 23, 513-522. doi:10.1080/09537287.2011.640040

Caldera, H.T.S., Desha, C., Dawes, L., 2019. Evaluating the enablers and barriers for successful implementation of sustainable business practice in 'lean' SMEs. J. Clean. Prod. 218, 575-590. doi:10.1016/j.jclepro.2019.01.239

Carvalho, H., Duarte, S., Machado, V.C., 2011. Lean, agile, resilient and green: divergencies and synergies. Int. J. Lean Six Sigma 2, 151-179. doi:10.1108/20401461111135037

Chiarini, A., 2011. Integrating lean thinking into ISO 9001: a first guideline. Int. J. Lean Six Sigma 2, 96-117. doi:10.1108/20401461111135000

Cudney, E., Elrod, C., 2011. A comparative analysis of integrating lean concepts into supply chain management in manufacturing and service industries. Int. J. Lean Six Sigma 2, 5-22. doi:10.1108/20401461111119422

Detty, R.B., Yingling, J.C., 2010. International Journal of Quantifying benefits of conversion to lean manufacturing with discrete event simulation : A case study 37-41. doi:10.1080/002075400189509

Drohomeretski, E., Gouvea da Costa, S.E., Pinheiro de Lima, E., Garbuio, P.A.D.R., 2014. Lean, Six Sigma and Lean Six Sigma: an analysis based on operations strategy. Int. J. Prod. Res. 52, 804-824. doi:10.1080/00207543.2013.842015

Duarte, S., Cruz-Machado, V., 2009. Modelling Lean and Green: a review from Business models. Int. J. Lean Six Sigma 4, 1-23. doi:10.1108/IJLSS-05-2013-0030

Farias, L.M.S., Santos, L.C., Gohr, C.F., Oliveira, L.C. de, Amorim, M.H. da S., 2019. Criteria and practices for lean and green performance assessment: Systematic review and conceptual framework. J. Clean. Prod. 218, 746-762. doi:10.1016/j.jclepro.2019.02.042

Fercoq, A., Lamouri, S., Carbone, V., 2016. Lean/Green integration focused on waste reduction techniques. J. Clean. Prod. 137, 567-578. doi:10.1016/j.jclepro.2016.07.107

Gandhi, N.S., Thanki, S.J., Thakkar, J.J., 2018. Ranking of drivers for integrated lean-green manufacturing for Indian manufacturing SMEs. J. Clean. Prod. 171, 675-689. doi:10.1016/j.jclepro.2017.10.041

Gao, S., Low, S.P., 2014. The Toyota Way model: An alternative framework for lean construction. Total Qual. Manag. Bus. Excell. 25, 664-682. doi:10.1080/14783363.2013.820022

Garza-Reyes, J.A., Al-Balushi, M., Antony, J., Kumar, V., 2016. A Lean Six Sigma framework for the reduction of ship loading commercial time in the iron ore pelletising industry. Prod. Plan. Control 1-20. doi:10.1080/09537287.2016.1185188

Green, J.C., Lee, J., Kozman, T.A., 2010. Managing lean manufacturing in material handling operations. Int. J. Prod. Res. 48, 2975-2993. doi:10.1080/00207540902791819

Gupta, S., Jain, S.K., 2013. A literature review of lean manufacturing. Int. J. Manag. Sci. Eng. Manag. 8, 241249. doi:10.1080/17509653.2013.825074

Gurumurthy, A., Kodali, R., 2008. A multi-criteria decision-making model for the justification of lean manufacturing systems. Int. J. Manag. Sci. Eng. Manag. 3, 100-118. 
doi:10.1080/17509653.2008.10671039

Gwo-Hshiung, T., Jih-Jang Huang, 2010. Multiple attribute decision making: methods and applications, CRC Press. Boca Raton.

Helleno, A.L., de Moraes, A.J.I., Simon, A.T., Helleno, A.L., 2017. Integrating sustainability indicators and Lean Manufacturing to assess manufacturing processes: Application case studies in Brazilian industry. J. Clean. Prod. 153, 405-416. doi:10.1016/j.jclepro.2016.12.072

Henao, R., Sarache, W., Gómez, I., 2019. Lean manufacturing and sustainable performance: Trends and future challenges. J. Clean. Prod. 208, 99-116. doi:10.1016/j.jclepro.2018.10.116

Hodge, G.L., Ross, K.G., Joines, J.A., Thoney, K., Hodge, G.L., Ross, K.G., Joines, J.A., Thoney, K., 2011. Adapting lean manufacturing principles to the textile industry Adapting lean manufacturing principles to the textile industry. Prod. Plan. Control Manag. Oper. 22, 237-247. doi:10.1080/09537287.2010.498577

Hofer, C., Eroglu, C., Rossiter Hofer, A., 2012. The effect of lean production on financial performance: The mediating role of inventory leanness. Int. J. Prod. Econ. 138, 242-253. doi:10.1016/j.ijpe.2012.03.025

Huo, B., Gu, M., Wang, Z., 2019. Green or lean? A supply chain approach to sustainable performance. J. Clean. Prod. 216, 152-166. doi:10.1016/j.jclepro.2019.01.141

Hussain, M., Malik, M., Al Neyadi, H.S., 2016. AHP framework to assist lean deployment in Abu Dhabi public healthcare delivery system, Business Process Management Journal. doi:10.1108/BPMJ-08-2014-0074

Jadhav, Jagdish R, Mantha, S., B. Rane, S., 2014. Exploring barriers in lean implementation. Int. J. Lean Six Sigma 5, 122-148. doi:10.1108/IJLSS-12-2012-0014

Jadhav, J R, Mantha, S.S., Rane, S.B., 2014. Roadmap for Lean implementation in Indian automotive component manufacturing industry: comparative study of UNIDO Model and ISM Model. doi:10.1007/s40092-014-0074-6

Jasti, N.V.K., Sharma, A., 2014. Lean manufacturing implementation using value stream mapping as a tool: A case study from auto components industry. Int. J. Lean Six Sigma 5, 89-116. doi:10.1108/IJLSS-04-20120002

Johansen, E., Walter, L., 2007. Lean Construction: Prospects for the German construction industry. Lean Constr. J. 3, 19-32.

Julia, A., Forno, D., Pereira, F.A., Forcellini, F.A., Kipper, L.M., 2014. Value Stream Mapping : a study about the problems and challenges found in the literature from the past 15 years about application of Lean tools. Int. J. Adv. Manuf. Technol. 72, 779-790. doi:10.1007/s00170-014-5712-z

Kumar Arya, A., Kumar Jain, S., 2014. Impacts of Kaizen in a small-scale industry of India: a case study. Int. J. Lean Six Sigma 5, 22-44. doi:10.1108/IJLSS-03-2013-0019

Kurilova-Palisaitiene, J., Sundin, E., Poksinska, B., 2018. Remanufacturing challenges and possible lean improvements. J. Clean. Prod. 172, 3225-3236. doi:10.1016/j.jclepro.2017.11.023

Leme, R.D., Nunes, A.O., Message Costa, L.B., Silva, D.A.L., 2018. Creating value with less impact: Lean, green and eco-efficiency in a metalworking industry towards a cleaner production. J. Clean. Prod. 196, 517-534. doi:10.1016/j.jclepro.2018.06.064

Luthra, S., Mangla, S.K., Yadav, G., 2019. An analysis of causal relationships among challenges impeding redistributed manufacturing in emerging economies. J. Clean. Prod. 225, 949-962. doi:10.1016/j.jclepro.2019.04.011 
Lyons, A.C., Vidamour, K., Jain, R., Sutherland, M., 2013. Developing an understanding of lean thinking in process industries. Prod. Plan. Control Manag. Oper. 24, 475-494. doi:10.1080/09537287.2011.633576

Machado, V.C., Leitner, U., 2010. Lean tools and lean transformation process in health care. Int. J. Manag. Sci. 5, 383-392. doi:10.1080/17509653.2010.10671129

Machado, V.C., Tavares, J., 2008. Value streams based strategy : modeling for lean management performance. Int. J. Manag. Sci. Eng. Manag. 3, 54-62. doi:10.1080/17509653.2008.10671035

Malekzadeh, G., Mostaffa Kazemi, Lagzian, M., Mortazavi, S., 2016. Modeling organizational intelligence using DEMATEL method in Iranian public universities. J. Model. Manag. 11, 134-153. doi:10.1108/EL01-2014-0022

Mangla, S.K., Sharma, Y.K., Patil, P.P., Yadav, G., Xu, J., 2019. Logistics and distribution challenges to managing operations for corporate sustainability: Study on leading Indian diary organizations. J. Clean. Prod. 117620. doi:10.1016/j.jclepro.2019.117620

Manzouri, M., Nizam Ab Rahman, M., Saibani, N., Rosmawati Che Mohd Zain, C., 2013. Lean supply chain practices in the Halal food. Int. J. Lean Six Sigma 4, 389-408. doi:10.1108/IJLSS-10-2012-0011

Marinescu, P., Toma, S.G., 2008. Implementing Lean Management in the Romanian Industry 257, $269-276$.

Marksberry, P., 2011. The Toyota Way - a quantitative approach. Int. J. Lean Six Sigma 2, 132-150. doi:10.1108/20401461111135028

Marodin, G.A., Saurin, T.A., 2013. Implementing lean production systems : research areas and opportunities for future studies. Int. J. Prod. Res. 51, 6633-6680. doi:10.1080/00207543.2013.826831

Mathur, A., Mittal, M.L., Dangayach, G.S., 2012. Improving productivity in Indian SMEs. Prod. Plan. Control 23, 754-758. doi:10.1080/09537287.2011.642150

Matt, D.T., Rauch, E., 2013. Implementation of Lean Production in small sized Enterprises. Procedia CIRP 12, 420-425. doi:10.1016/j.procir.2013.09.072

Mcdonald, T., Ellis, K.P., Aken, E.M. Van, 2009. Development and application of a worker assignment model to evaluate a lean manufacturing cell. Int. J. Prod. Res. 47, 2247-2447. doi:10.1080/00207540701570174

Mehregan, M.R., Hashemi, S.H., Karimi, A., Merikhi, B., 2014. Analysis of interactions among sustainability supplier selection criteria using ISM and fuzzy DEMATEL. Int. J. Appl. Decis. Sci. 7, 270. doi:10.1504/IJADS.2014.063226

Moyano-Fuentes, J., Sacristán-Díaz, M., 2012. Learning on lean: a review of thinking and research. Int. J. Oper. Prod. Manag. 32, 551-582. doi:10.1108/01443571211226498

Pakdil, F., Leonard, K.M., 2014. Criteria for a lean organisation : development of a lean assessment tool. Int. J. Prod. Res. 52, 4587-4607. doi:10.1080/00207543.2013.879614

Panizzolo, R., 1998. Applying the lessons learned from 27 lean manufacturers . The relevance of relationships management. Int. J. Prod. Econ. 55, 223-240.

Panizzolo, R., Garengo, P., Sharma, M.K., Gore, A., 2012. Lean manufacturing in developing countries : evidence from Indian SMEs. Prod. Plan. Control Manag. Oper. 23, 769-788. doi:10.1080/09537287.2011.642155

Panwar, A., Jain, R., Rathore, A.P.S., 2015. Lean implementation in Indian process industries - some empirical evidence. J. Manuf. Technol. Manag. 26, 131-160.

Pavnaskar, S.J., Gershenson, J.K., Jambekar, A.B., 2003. Classification scheme for lean manufacturing tools. 
Int. J. Prod. Res. 41, 3075-3090. doi:10.1080/0020754021000049817

Pernstål, J., Feldt, R., Gorschek, T., 2015. The Journal of Systems and Software The lean gap : A review of lean approaches to large-scale software systems development. J. Syst. Softw. 86, 2797-2821. doi:10.1016/j.jss.2013.06.035

Peter Hasle, Anders Bojesen, Per Langaa Jensen, P.B., Hasle, P., Bojesen, A., Per Langaa, J., Bramming, P., 2012. Lean and the working environment: a review of the literature. Int. J. Oper. Prod. Manag. 32, 829849. doi:10.1108/01443571211250103

Rad, T.G., Sadeghi-Niaraki, A., Abbasi, A., Choi, S.-M., 2017. A methodological framework for assessment of ubiquitous cities using $\{$ ANP $\}$ and $\{$ DEMATEL $\}$ methods. Sustain. Cities Soc. doi:https://doi.org/10.1016/j.scs.2017.11.024

Rahman, A., Karim, A., 2014. Application of lean production to reducing operational waste in a tile manufacturing process. Int. J. Manag. Sci. Eng. Manag. 8, 126-134. doi:10.1080/17509653.2013.798948

Ramesh, V., Kodali, R., 2012. A decision framework for maximising lean manufacturing performance. Int. J. Prod. Res. 50, 2234-2251. doi:10.1080/00207543.2011.564665

Ramos, A.R., Ferreira, J.C.E., Kumar, V., Garza-Reyes, J.A., Cherrafi, A., 2018. A lean and cleaner production benchmarking method for sustainability assessment: A study of manufacturing companies in Brazil. J. Clean. Prod. 177, 218-231. doi:10.1016/j.jclepro.2017.12.145

S Vinodh, K R Arvind, Somanaathan, M., 2011. Tools and techniques for enabling sustainability through lean initiatives. Clean Technol. Environ. Policy 13, 469-479. doi:10.1007/s10098-010-0329-x

Seth, D., Panigrahi, A., 2015. Application and evaluation of packaging postponement strategy to boost supply chain responsiveness: a case study. Prod. Plan. Control 26, 1069-1089. doi:10.1080/09537287.2015.1010626

Setijono, D., Mohajeri Naraghi, A., Pavan Ravipati, U., 2010. Decision support system and the adoption of lean in a Swedish emergency ward. Int. J. Lean Six Sigma 1, 234-248. doi:10.1108/20401461011075026

Seyedhosseini, S.M., Taleghani, A.E., Makui, A., 2013. Fuzzy value stream mapping in multiple production streams: A case study in a parts manufacturing company. Int. J. Manag. Sci. Eng. Manag. 8, 56-66. doi:10.1080/17509653.2013.783190

Shah, R., Ward, P.T., 2007. Defining and developing measures of lean production. J. Oper. Manag. 25, 785805. doi:10.1016/j.jom.2007.01.019

Shamah, R. a. M., 2013a. A model for applying lean thinking to value creation. Int. J. Lean Six Sigma 4, $204-$ 224. doi:10.1108/20401461311319365

Shamah, R. a. M., 2013b. Measuring and building lean thinking for value creation in supply chains. Int. J. Lean Six Sigma 4, 17-35. doi:10.1108/20401461311310490

Shetty, D., Ali, A., Cummings, R., 2010. Survey $\square$ based spreadsheet model on lean implementation. Int. J. Lean Six Sigma 1, 310-334. doi:10.1108/20401461011096087

Singer, E., Becker, K., 2013. A single $\square$ source content management system for lean manufacturing. Int. J. Lean Six Sigma 4, 83-103. doi:10.1108/20401461311310535

Singh, B., Garg, S.K., Sharma, S.K., Grewal, C., 2010. Lean implementation and its benefits to production industry. Int. J. Lean Six Sigma 1, 157-168. doi:10.1108/20401461011049520

Soriano $\square$ Meier, H., Forrester, P.L., Markose, S., Arturo Garza $\square$ Reyes, J., 2011. The role of the physical layout 
in the implementation of lean management initiatives. Int. J. Lean Six Sigma 2, 254-269. doi:10.1108/20401461111157204

Stentoft Arlbjørn, J., Vagn Freytag, P., 2013. Evidence of lean: a review of international peer $\square$ reviewed journal articles. Eur. Bus. Rev. 25, 174-205. doi:10.1108/09555341311302675

Storch, R.L., Lim, S., 1999. Improving flow to achieve lean manufacturing in shipbuilding. Prod. Plan. Control Manag. Oper. 10, 127-137. doi:10.1080/095372899233280

Su, C.-M., Horng, D.-J., Tseng, M.-L., Chiu, A.S.F., Wu, K.-J., Chen, H.-P., 2016. Improving sustainable supply chain management using a novel hierarchical grey-DEMATEL approach. J. Clean. Prod. 134, 469481. doi:10.1016/j.jclepro.2015.05.080

Thanki, S., Govindan, K., Thakkar, J., 2016. An investigation on lean-green implementation practices in Indian SMEs using analytical hierarchy process (AHP) approach. J. Clean. Prod. 135, 284-298. doi:10.1016/j.jclepro.2016.06.105

Thanki, S.J., Thakkar, J., 2014. Status of lean manufacturing practices in Indian industries and government initiatives. J. Manuf. Technol. Manag. 25, 665-675. doi:10.1108/JMTM-05-2012-0057

Thomas, A.J., Francis, M., Fisher, R., Byard, P., 2016. Implementing Lean Six Sigma to overcome the production challenges in an aerospace company. Prod. Plan. Control 7287, 591-603. doi:10.1080/09537287.2016.1165300

Tranfield, D., Denyer, D., Smart, P., 2003. Towards a Methodology for Developing Evidence-Informed Management Knowledge by Means of Systematic Review. Br. J. Manag. 14, 207-222. doi:10.1111/14678551.00375

Tzeng, G.H., Chiang, C.H., Li, C.W., 2007. Evaluating intertwined effects in e-learning programs: A novel hybrid MCDM model based on factor analysis and DEMATEL. Expert Syst. Appl. 32, 1028-1044. doi:10.1016/j.eswa.2006.02.004

Upadhye, N., Deshmukh, S.G., Garg, S., 2010. Lean manufacturing system for medium size manufacturing enterprises: an Indian case. Int. J. Manag. Sci. Eng. Manag. 5, 362-375. doi:10.1080/17509653.2010.10671127

Uygun, Ö., Kaçamak, H., Kahraman, Ü.A., 2014. An integrated DEMATEL and Fuzzy ANP techniques for evaluation and selection of outsourcing provider for a telecommunication company. Comput. Ind. Eng. 86, 137-146. doi:10.1016/j.cie.2014.09.014

Vamsi Kishna Jasti, N., Kodali, R., 2014. Validity and reliability of lean manufacturing frameworks, International Journal of Lean Six Sigma. doi:10.1108/IJLSS-12-2013-0057

Vamsi Krishna Jasti, N., Kodali, R., 2014. A literature review of empirical research methodology in lean manufacturing. Int. J. Oper. Prod. Manag. 34, 1080-1122. doi:10.1108/IJOPM-04-2012-0169

Vinodh, S., Joy, D., 2012. Structural Equation Modelling of lean manufacturing practices. Int. J. Prod. Res. 50, 1598-1607. doi:10.1080/00207543.2011.560203

Waterbury, T., Bonilla, C., 2008. A Lean Six Sigma execution strategy for service sectors: what you need to know before starting the journey. Int. J. Six Sigma Compet. Advant. 4, 395-408. doi:10.1504/IJSSCA.2008.022951

Yadav, G., Desai, T.N., 2017a. Analyzing Lean Six Sigma enablers: A hybrid ISM-fuzzy MICMAC approach. TQM J. 29, 488-511. doi:10.1108/TQM-04-2016-0041 
Yadav, G., Desai, T.N., 2017b. A fuzzy AHP approach to prioritize the barriers of integrated Lean Six Sigma. Int. J. Qual. Reliab. Manag. 34. doi:10.1108/IJQRM-01-2016-0010

Yadav, G., Desai, T.N., 2016. Lean Six Sigma: a categorized review of the literature. Int. J. Lean Six Sigma 7. doi:10.1108/IJLSS-05-2015-0015

Yadav, G., Mangla, S.K., Luthra, S., Jakhar, S., 2018a. Hybrid BWM-ELECTRE-based decision framework for effective offshore outsourcing adoption: a case study. Int. J. Prod. Res. 56, 6259-6278. doi:10.1080/00207543.2018.1472406

Yadav, Gunjan, Seth, D., Desai, T.N., 2018. Application of hybrid framework to facilitate lean six sigma implementation: a manufacturing company case experience. Prod. Plan. Control 29, 185-201. doi:10.1080/09537287.2017.1402134

Yadav, G., Seth, D., Desai, T.N., 2018b. Prioritising solutions for Lean Six Sigma adoption barriers through fuzzy AHP-modified TOPSIS framework. Int. J. Lean Six Sigma 9, 270-300. doi:10.1108/IJLSS-062016-0023

Yadav, G., Seth, D., Desai, T.N., 2017. Analysis of research trends and constructs in context to lean six sigma frameworks. J. Manuf. Technol. Manag. 28, 794-821. doi:10.1108/JMTM-03-2017-0043

Zargun, S., Al-Ashaab, A., 2013. Critical Success Factors for Lean Manufacturing: A Systematic Literature Review an International Comparison between Developing and Developed Countries. Adv. Mater. Res. 845, 668-681. doi:10.4028/www.scientific.net/AMR.845.668

Zhou, B., 2016. Lean principles, practices , and impacts : a study on small and medium-sized enterprises ( SMEs ). Ann. Oper. Res. 241, 457-474. doi:10.1007/s10479-012-1177-3 


\section{Research Highlights}

- Studied existing Lean Manufacturing (LM) frameworks

- Proposed LM framework to enhance its adoption

- Documented drivers of LM among the manufacturing industries of emerging economies

- Implemented the developed framework in a pump manufacturing organisation

- Documented improvements in organisational performance metrics 